$\mathrm{AD}$

Award Number: DAMD17-00-1-0080

TITLE: The Emory University Prostate Cancer Center Initiation Program

PRINCIPAL INVESTIGATOR: John A. Petros, M.D.

CONTRACTING ORGANIZATION: Emory University

Atlanta, Georgia 30322

REPORT DATE: April 2002

TYPE OF REPORT: Annual

PREPARED FOR: U.S. Army Medical Research and Materiel Command Fort Detrick, Maryland 21702-5012

DISTRIBUTION STATEMENT: Approved for public release;

Distribution unlimited

The views, opinions and/or findings contained in this report are those of the author(s) and should not be construed as an official Department of the Army position, policy or decision unless so designated by other documentation. 
- REPORT DOCUMENTATION PAGE

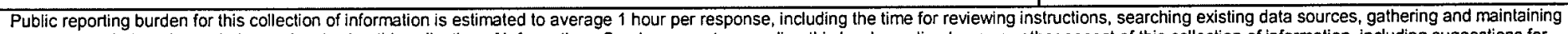

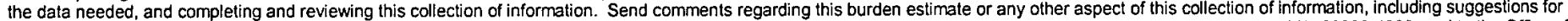

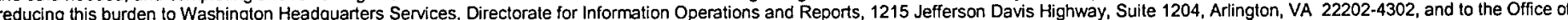

Management and Budget, Paperwork Reduction Project (0704-0188). Washington, DC 20503

1. AGENCY USE ONLY (Leave blank) 2. REPORT DATE 3. REPORT TYPE AND DATES COVERED April 2002 Annual (1 Apr $01-31$ Mar 02)

4. TITLE AND SUBTITLE

The Emory University Prostate Cancer Center Initiation Award

6. AUTHOR(S)

John A. Petros, M.D.

7. PERFORMING ORGANIZATION NAME(S) AND ADDRESS(ES

Emory University

Atlanta, Georgia 30322

\section{PERFORMING ORGANIZATION} REPORT NUMBER

E-Mail:jpetros@emory.edu

\section{SPONSORING / MONITORING AGENCY NAME(S) AND ADDRESS(ES)}

U.S. Army Medical Research and Materiel Command

Fort Detrick, Maryland 21702-5012

DAMD 17-00-1-0080

\section{SUPPLEMENTARY NOTES}

12a. DISTRIBUTION / AVAILABILITY STATEMENT

Approved for public release; distribution unlimited

10. SPONSORING / MONITORING AGENCY REPORT NUMBER

13. Abstract (Maximum 200 Words) (abstract should contain no proprietary or confidential information)

Continued productivity in the second year of the three year award included publications, presentations and new cell lines. Progress was made on all aims in all projects.

Projects 1 and 2 have both resulted in NIH ROI applications and an NIH POI application.

\begin{tabular}{|l|l|l|}
\hline $\begin{array}{l}\text { 14. SUBJECT TERMS } \\
\text { Prostate cancer, mitochondrial DNA, oxidase, MUC } 18\end{array}$ \\
$\begin{array}{c}\text { 17. SECURITY CLASSIFICATION } \\
\text { OF REPORT } \\
\text { Unclassified }\end{array}$ & $\begin{array}{c}\text { 18. SECURITY CLASSIFICATION } \\
\text { OF THIS PAGE } \\
\text { Unclassified }\end{array}$ & $\begin{array}{c}\text { 19. SECURITY CLASSIFICATION } \\
\text { OF ABSTRACT } \\
\text { UnClassified }\end{array}$ \\
\hline
\end{tabular}




\section{Table of Contents}

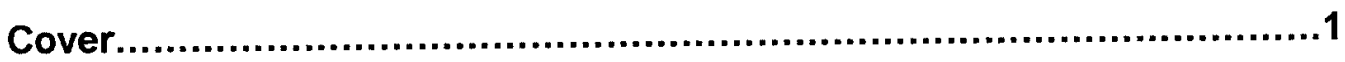

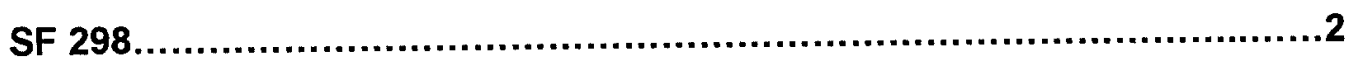

Table of Contents........................................................................

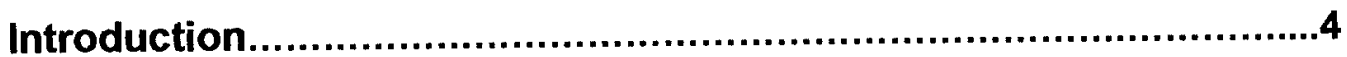

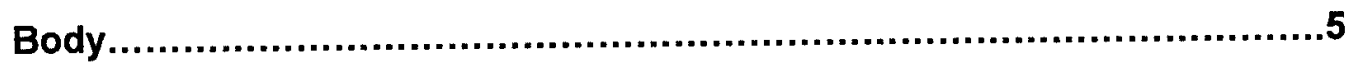

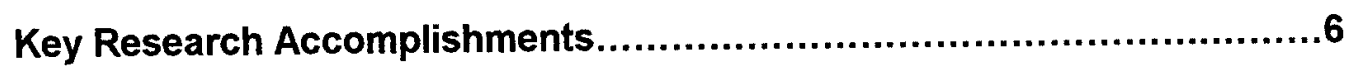

Reportable Outcomes...............................................................

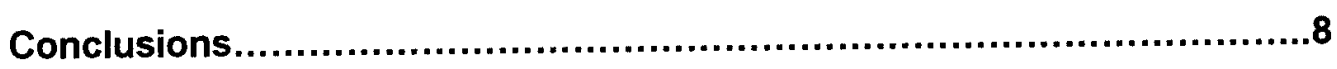

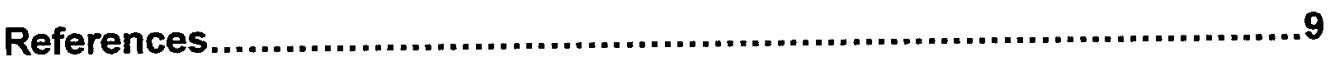

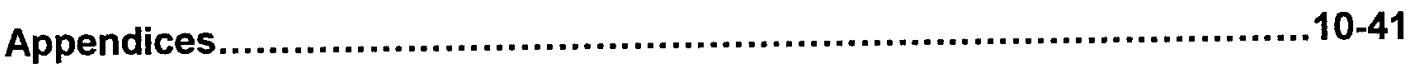




\section{INTRODUCTION}

The project supports 3 separate research projects and one core facility designed to investigate basic science aspects of prostate cancer including mitogenic oxidase expression (Project 1), mitochondrial DNA mutations (Project 2), and the cell adhesion molecule MUC-18 (Project 3). In addition, the project is designed to aid in initiating a multi-disciplinary prostate cancer research center and to assist investigators in obtaining other extra-mural funding for these projects. This has largely been accomplished with peer-reviewed publication and presentations at national scientific meetings resulting from each of the three projects. In addition, 2 RO1 applications and one PO1 application are the direct result of work accomplished by this award. A highly collaborative group has been established at Emory and critical resources have been obtained such as laser-capture dissected clinical specimens and novel cell lines. 


\section{BODY}

\section{Research Project 1.}

Significant accomplishments of this project include the identification of prostate cancerspecific expression of NOX-1 in clinical prostate cancer specimens. In addition, the transfection of the human prostate cancer cell line DU-145 with a Nox-1 construct has demonstrated that Nox-1 triggers the angiogenic switch (Arbiser et al, PNAS 2002: attached). Unpublished data including the generation of nox-1 transgenic mice is considered preliminary at this point but it is believed that 2 transgenic founders have been established.

\section{Research Project 2.}

The publication of Jessie et al (Experimental Gerontology, attached) has demonstrated that mitochondrial DNA deletion mutations accumulate with age in the malignant prostate. In addition, several new mutations have been identified in clinical prostate specimens (unpublished). An RO1 application by the PI of this project (Petros) has been favorably reviewed and received a fundable score (percentile 15.8, NCI). Dr. Petros has been an invited speaker at the AACR annual meeting on the topic of mtDNA mutations in prostate cancer.

\section{Research Project 3.}

Dr. Wu has published in Gene during this funding period (attached) that MUC-18 expression correlates with malignant potential of prostate cancer. In addition, an abstract was presented at this year's AACR demonstrating that MUC-18 over-expression increased metastasis (see reportable outcomes). Novel derivative cell lines have been made that express MUC-18.

\section{Core Facility.}

Dr. Amin has continued to provide laser-capture microdissected clinical specimens in support of all research projects and has assisted in the immunohistochemical analysis for Dr. Wu's publication (\#3 above). Support from the award has allowed the retention of key personnel involved in these aspects of the core facility. 


\section{KEY RESEARCH ACCOMPLISHMENTS}

- Demonstration that Nox-1 is over-expressed in clinical prostate cancer

- Demonstration that Nox-1 triggers the angiogenic switch

- Creation of Nox-1 transgenic mouse founder lines

- Demonstration that mtDNA mutations are common in clinical prostate cancer

- Demonstration that mtDNA deletions accumulate with age in the malignant prostate

- Demonstration that MUC-18 expression in clinical specimens correlates with malignant potential

- Demonstration that MUC-18 over-expression enhances prostate cancer metastases 
Reportable Outcomes (award personnel marked by bold type)

Publications:

Jessie BC, Sun CQ, Irons HR, Marshall FF, Wallace DC, Petros JA. Accumulation of mitochondrial DNA deletions in the malignant prostate of patients of different ages. Experimental Gerontology 37: 169-174, 2001.

Wu GJ, Wu MW, Wang SW, Liu Z, Qu P, Peng Q, Yang H, Varma VA, Sun QC, Petros JA, Lim SD, Amin MB. Isolation and characterization of the major form of human MUC18 cDNA gene and correlation of MUC18 over-expression in prostate cancer cell lines and tissues with malignant progression. Gene 279: 17-31, 2001

Arbiser JL, Petros J, Klafter R, Govindajaran B, McLaughlin ER, Brown LF, Cohen C, Moses M, Kilroy S, Arnold RS, Lambeth JD. Reactive oxygen generated by Nox1 triggers the angiogenic switch. Proceedings of the National Academy of Sciences 99: 715-720, 2002

Abstracts:

Wu GJ, Peng Q, Wang SW, Wu MW. MUC18 is required for the tumorigenesis and metastasis of human prostate cancer LNCaP cells. Proceedings of the American Association for Cancer Research 43: 1065, A5277, 2002

Cell Lines:

Wu (Project 3): Several cell lines derived from LNCaP that express MUC-18 Petros (Project 2): Cybrid cell lines with the 8993 mutation in PC3.

Arnold (Project 1): Nox-1 expressing lines derived from DU-145. 


\section{CONCLUSIONS}

The prostate cancer center at Emory has been significantly enabled through this award. The multi-disciplinary approach has proved effective with the continued development of clinical specimens and outcomes for use by basic science researchers. Each of the three projects central hypotheses are being proven correct and this has allowed several highprofile publications. Novel findings include the importance of oxidases, mtDNA mutations and MUC-18 in clinical prostate cancer and in each case the development of appropriate laboratory models. In addition to publications, significant grant applications have arisen from this award including $\mathrm{RO} 1$ and PO1 applications. The prostate cancer research community at Emory has been significantly expanded during the term of this award. 


\section{REFERENCES}

Jessie BC, Sun CQ, Irons HR, Marshall FF, Wallace DC, Petros JA. Accumulation of mitochondrial DNA deletions in the malignant prostate of patients of different ages.

Experimental Gerontology 37: 169-174, 2001.

Wu GJ, Wu MW, Wang SW, Liu Z, Qu P, Peng Q, Yang H, Varma VA, Sun QC, Petros JA, Lim SD, Amin MB. Isolation and characterization of the major form of human MUC18 cDNA gene and correlation of MUC18 over-expression in prostate cancer cell lines and tissues with malignant progression. Gene 279: 17-31, 2001

Arbiser JL, Petros J, Klafter R, Govindajaran B, McLaughlin ER, Brown LF, Cohen C, Moses M, Kilroy S, Arnold RS, Lambeth JD. Reactive oxygen generated by Nox1 triggers the angiogenic switch. Proceedings of the National Academy of Sciences 99: $715-720,2002$

Wu GJ, Peng Q, Wang SW, Wu MW. MUC18 is required for the tumorigenesis and metastasis of human prostate cancer LNCaP cells. Proceedings of the American Association for Cancer Research 43: 1065, A5277, 2002 


\title{
EXPERIMENTAL GERONTOLOGY
}

Experimental Gerontology 37 (2001) 169-174

Short Communication

Accumulation of mitochondrial DNA deletions in the malignant. prostate of patients of different ages

\author{
Benjamin C. Jessie ${ }^{a}$, Carrie Q. Sun ${ }^{\text {a.b }}$, Hillary R. Irons ${ }^{a, b}$, Fray F. Marshall ${ }^{a, b}$, \\ Douglas C. Wallace ${ }^{c}$ John A. Petros ${ }^{a, b, d, *}$ \\ Winship Cancer Institute. 1365B Clifton Road, NE, Astanta, GA 30322, USA \\ 'Department of Urology: Emory University School of Medicine, 1365 Clifton Road, NE, Atlanta, GA 30322, USA \\ 'Center for Molecular Medicine. 1462 Clifton Road, NE. Atlanta, GA 30322, USA \\ 'The Atlanta VA Medical Center, 1670 Clarimont Road, NE. Decatur, GA 30033, USA
}




\section{EXPERIMENTAL GERONTOLOGY Affiliated with the International Association of Gerontology}

Editor-in-Chief

GEORG WICK

Institute for Biomedical Aging Research of the Austrian

Academy of Sciences

Rennweg 10, A-6020 Innsbruck, Austria

Tel: +43-512-5839-19-15

Fax: +43-512-5839-19-8

E-mail: exp.gerontol@oeaw.ac.at
Managing Editor

BEATRIX GRUBECK-LOEBENSTEIN

Innsbruck, Austria

Associate Editors

PETER BERGER, Innsbruck, Austria

PIDDER JANSEN-DUERR, Innsbruck, Austria

GEORGE S. ROTH, Baltimore, MD, USA

RUDOLPH TANZI, Charlestown, MA, USA
Michael Breitenbach Salzburg, Austria

Henry G. Burger

Clayton, Victoria, Australia

Vincent J. Cristofalo

Wynnewood, PA, USA

J. Fred Dice

Boston, MA, USA

Rita B. Effros

Los Angeles, CA, USA

Caleb E. Finch

Los Angeles, CA, USA

Claudio Franceschi

Bologna, Italy

Michael Freissmuth

Wien, Austria

David Gershon

Haifa, Israel

Amiela Globerson

Beersheva, Israel

Katsuiku Hirokawa

Tokyo, Japan

S. Michal Jazwinski

New Orleans, LA, USA

Thomas E. Johnson

Boulder, CO, USA

James A. Joseph

Boston, MA, USA

Paul A. Kelly

Paris, France

\section{EDITORIAL BOARD}

Tom B.L. Kirkwood

Newcastle upon Tyne, UK

Dick L. Knook

Leiden, The Netherlands

Rodney L. Levine

Bethesda, MD, USA

Marco Londei

London, UK

George M. Martin

Seattle, WA, USA

Edward J. Masoro

San Antonio, TX, USA

Simon Melov

Novato, CA, USA

Richard A. Miller

Ann Arbor, MI, USA

Masayoshi Namba

Shikata, Okayama, Japan

Heinz D. Osiewacz

Frankfurt a. Main, Germany

Graham Pawelec

Tübingen, Germany

Gordon Peters

London, UK

Dieter Platt

Nümberg, Germany

Antonius G. Rolink

Basel, Switzerland

Michael R. Rose

Irvine, CA, USA
Gary B. Ruvkun

Boston, MA, USA

Paolo Sansoni

Parma, Italy

Christian Schöneich

Lawrence, KS, USA

Manuel Serrano

Madrid, Spain

Raj S. Sohal

Los Angeles, CA, USA

Elisabeth Steinhagen-Thiessen

Berlin, Germany

Olivier Toussaint

Namur, Belgium

Johannes $D$. Veldhuls

Charlottesville, VA, USA

Andrus Viidlk

Aarhus, Denmark

Richard Weindruch

Madison, WI, USA

Marc E. Weksler

New York, NY, USA

Rudi G. J. Westendorp

Leiden, The Netherlands

Joseph L. Witztum

La Jolla, CA, USA

Thomas von Zglinicki

Newcastle upon Tyne, UK

\section{BOOK EDITOR: Raj S. Sohal (Los Angeles; CA, USA) \\ FOUNDING EDITOR: Alex Comfort HONORARY EDITOR: Leonard Hayflick (San Francisco, CA, USA)}

Publlcation informatlon: Experimental Gerontology (ISSN 0537-5565). For 2002 volume 37 (12 issues) is scheduled for publication. Subscription prices are available upon request from the Publisher or from the Regional Sales Office nearest you or from this journal's website (http://www.elsevier.com/locate/exg). Further intormation is available on this journal and other Elsevier Science products website (http://www.elsevier.com/ocate/exg). Further intormation is available on this journal and other Elsevier science products through Elsevier's website: (http://wWw.elsevier.com). Subscriptions are accepted on a prepaid basis only and are entered on a
calendar year basis. Issues are sent by standard mail (surface within Europe, air delivery outside Europe). Priority rates are available upon request. Claims for missing issues should be made within six months of the date of dispatch.

Orders, claims, and product enquiries: please contact the Customer Support Department at the Regional Sales Office nearest you: New York: Elsevier Science, PO Box 945, New York, NY 10159-0945, USA; phone: (+1) (212) 633 3730 , [toll free number for North American customers: 1-888-4ES-INFO (437-4636)]; fax: (+1) (212) 6333680 ; e-mail: usinfo-f@ elsevier.com

Amsterdam: Elsevier Science, PO Box 211, 1000 AE Amsterdam, The Netherlands; phone: (+31) 20 4853757; fax: (+31) 20 4853432; e-mail: nlinfo-f@elsevier.nl

Tokyo: Elsevier Science, 9-15 Higashi-Azabu 1-chome, Minato-ku, Tokyo 106, Japan; phone: (+81) (3) 5561 5033; fax: (+81) (3) 55615047; e-mail: info@ elsevier.co.jp

Singapore: Elsevier Science, No. 1 Temasek Avenue, \#17-01 Millenia Tower, Singapore 039192; phone: (+65) 434 3727; fax: (+65) 337 2230; e-mail: asiainfo @elsevier.com.sg

Rio de Janeiro: Elsevier Science, Rua Sete de Setembro 111/16 Andar, 20050-002 Centro, Rio de Janeiro-RJ, Brazil; phone: (+55) (21) 509 5340; fax: (+55) (21) 507 1991; e-mait: elsevier Q campus.com.br [Note (Latin America): for orders, claims and help desk information, please contact the Regional Sales Office in New York as listed above]

US mailing notice: Experimental Gerontology (ISSN 0531-5565) is published twelve times a year, monthly, by Elsevier Science, (P.O. Box 211, 1000 AE Amsterdam, The Netherlands). Annual subscription price in the USA US $\$ 1385$ (valid in North, Central and South America only), including air speed delivery. Periodical postage rate paid at Jamaica, NY 11431.

USA POSTMASTER: Send address changes to Experimental Gerontology, Publications Expediting, Inc., 200 Meacham Avenue, Elmont, NY 11003

AIRFREIGHT AND MAILING in the USA by Publications Expediting, Inc., 200 Meacham Avenue, Elmont, NY 11003.

@The paper used in this publication meets the requirements of ANSI/NISO Z39.48-1992 (Permanence of Paper) 


\title{
Short Communication
}

\section{Accumulation of mitochondrial DNA deletions in the malignant prostate of patients of different ages}

\author{
Benjamin C. Jessie ${ }^{a}$, Carrie Q. Sun ${ }^{\mathrm{a}, \mathrm{b}}$, Hillary R. Irons ${ }^{\mathrm{a}, \mathrm{b}}$, Fray F. Marshall ${ }^{\mathrm{a}, \mathrm{b}}$, \\ Douglas C. Wallace ${ }^{c}$, John A. Petros ${ }^{a, b, d, *}$ \\ a'Winship Cancer Institute, 1365B Clifton Road, NE, Atlanta, GA 30322, USA \\ ${ }^{\mathrm{b}}$ Department of Urology, Emory University' School of Medicine, 1365 Clifton Road, NE, Atlanta, GA 30322, USA \\ ${ }^{\circ}$ Center for Molecular Medicine, 1462 Clifton Road, NE, Atlanta, GA 30322, USA \\ ${ }^{\mathrm{d}}$ The Atlanta VA Medical Center, 1670 Clarimont Road, NE, Decatur, GA 30033, USA
}

Received 30 May 2001; received in revised form 9 July 2001; accepted 13 July 2001

\begin{abstract}
It has been shown that mitochondrial DNA (mtDNA) deletion mutations accumulate with age in many tissues of the body. However, to date no one has shown that these deletions occur in the malignant prostate. Therefore, we hypothesize that such deletions do occur in the prostate and increasingly so with advanced age. To test this hypothesis, DNA was isolated from 34 radical prostatectomy specimens, and the entire mitochondrial genome $(16.5 \mathrm{~kb})$ was amplified using long range PCR (LXPCR). The LXPCR products were visualized by gel electrophoresis, and the presence of low molecular weight $(<16 \mathrm{~kb})$ bands was considered evidence of large mtDNA deletions. In order to show that these lower molecular weight LXPCR bands were not simply PCR artifact, we also digested mtDNA from a subset of the same patients and did Southern analysis with a mtDNA probe. Southern blots confirmed the existence of large deletions in every sample tested. Furthermore, several of the specific deletions identified by LXPCR were also seen in the Southern blots. From the LXPCR data, we found that as the age of the specimen increased, so did the average number of low molecular weight bands (i.e. deletions). In particular, one prominent band was seen at $1.2 \mathrm{~kb}$ and became more consistent with advanced age. (C) 2001 Elsevier Science Inc. All rights reserved.
\end{abstract}

Keywords: Mitochondrial DNA; Cellular aging; Long range PCR; Prostatic adenocarcinoma; Reactive oxygen

\section{Introduction}

Aging is a process that is associated with declining biochemical and physiological function of the cell. However, the exact cause of such decline is still the focus of much research. The free radical theory of

\footnotetext{
* Corresponding author. Address: Department of Urology, Emory University School of Medicine, 1365 Clifton Road, NE, Atlanta, GA 30322, USA. Tel.: +1-404-778-4847; fax: +1-404-778-50-16.

E-mail address: jpetros@emory.edu (J.A. Petros).
}

aging proposed by Harman about 45 years ago, however, has continued to gain support and acceptance (Harman, 1956). In fact, many researchers have shown that oxidative stress does cause cellular damage which increases with chronological age (Ames, 1989; Fraga et al., 1990). This increase in damage with time is one of the cellular signatures of aging.

Important strides have been made in determining the origin of the increasing levels of free radicals in aging cells. Of particular importance is the increase of 
Table 1

Age and gleason grade of tumor specimens corresponding to Fig. 1(a)

\begin{tabular}{llllll}
\hline Lane & Age & Gleason grade & Lane & Age & Gleason grade \\
\hline 1 & 41 & $3+3$ & 18 & 60 & $3+4$ \\
2 & 43 & $3+4$ & 19 & 61 & $3+3$ \\
3 & 44 & $3+3$ & 20 & 62 & $3+4$ \\
4 & 45 & $3+3$ & 21 & 64 & $4+5$ \\
5 & 47 & $3+3$ & 22 & 65 & $3+4$ \\
6 & 48 & $4+5$ & 23 & 66 & $3+4$ \\
7 & 50 & $3+3$ & 24 & 67 & $3+3$ \\
8 & 50 & $3+4$ & 25 & 68 & $3+4$ \\
9 & 51 & $3+3$ & 26 & 69 & $4+4$ \\
10 & 52 & $3+4$ & 27 & 70 & $3+3$ \\
11 & 53 & $3+3$ & 28 & 71 & $3+4$ \\
12 & 54 & $3+3$ & 29 & 72 & $3+2$ \\
13 & 55 & $3+3$ & 30 & 73 & $3+4$ \\
14 & 56 & $3+4$ & 31 & 75 & $3+4$ \\
15 & 57 & $3+4$ & 32 & 78 & $3+4$ \\
16 & 58 & $3+3$ & 33 & 79 & $3+3$ \\
17 & 59 & $3+3$ & 34 & 81 & $3+4$ \\
\hline
\end{tabular}

oxidative by-products released by the mitochondria of the aging cell (Sohal and Sohal, 1991). Since the mitochondrion is the cellular location of most oxygen utilization and energy production, under normal circumstances most cellular reactive oxygen is produced by and released from this organelle. Thus, mitochondrial production of reactive oxygen is important in cellular aging and has become the focus of much research in recent years.

Since reactive oxygen has been implicated in aging, and mitochondria increase the production of oxidative by-products over time, it seems plausible that mitochondria play a central role in the aging process. However, why do mitochondria increase the production of reactive oxygen in the aging cell? The simple answer is that mitochondrial electron transport becomes less efficient with time and electrons from the transport chain react with molecular oxygen forming reactive species. However, the question remains as to why mitochondrial electron transport becomes less efficient over time.

To date most studies dealing with mitochondria and increasing oxidative stress have focused on the mitochondrial genome, a circular strand of DNA (approximately $16 \mathrm{~kb}$ ) which encodes 13 proteins essential for cellular energy production. Since this genome lacks protective histones and has a limited DNA repair ability, mutations can accumulate over time. The accumulation of these mutations is hypothesized to decrease the efficiency of oxygen utilization and energy production of the mitochondria leading to an increase in oxidative stress. These mitochondrial DNA (mtDNA) mutations have been show to accumulate in various tissues throughout the body including skeletal muscle (Lee et al., 1994; Melov et al., 1995, 1997). However, no one has shown these mutations to accumulate in the aging prostate. Thus, we designed this project in order to assess the qualitative increase of mitochondrial deletions in the older malignant prostate.

\section{Materials and methods}

\subsection{Prostate specimens}

Radical prostatectomy specimens were obtained from the Emory University Tissue Procurement facility after being immediately frozen in liquid nitrogen and stored at $-80^{\circ} \mathrm{C}$. The Gleason grade and age of each specimen used in the study can be seen in Table 1.

\subsection{DNA isolation}

Thirty-four frozen prostatectomy specimens from patients aged 41-81 (not all ages included) were frozen in liquid nitrogen and mechanically ground to a fine powder. DNA was then isolated and purified using a Qiagen Blood and Cell Culture DNA Midi Kit (Cat. \#13343) in order to maintain integrity of high molecular weight DNA molecules.

\subsection{Mitochondrial DNA amplification}

A hot start, long range PCR (LXPCR) was performed on DNA samples as described previously with a few alterations (Melov et al., 1995). The primers used (For - TGA GGC CAA ATA TCA TTC TGA GGG GC; Rev — TTT CAT CAT GAG ATG TTG GAT GG) were opposing primers located in the cyt $b$ gene allowing for full genome replication (approximately $16 \mathrm{~kb}$ ). A $30 \mu \mathrm{l}$ bottom phase consisting of $0.2 \mathrm{mM}$ For primer, $0.2 \mathrm{mM}$ Rev primer, $300 \mathrm{mM}$ dNTP (Amersham Pharmacia Biotech PCR nucleotide mix; cat \#US77212), 1U Taq polymerase, 


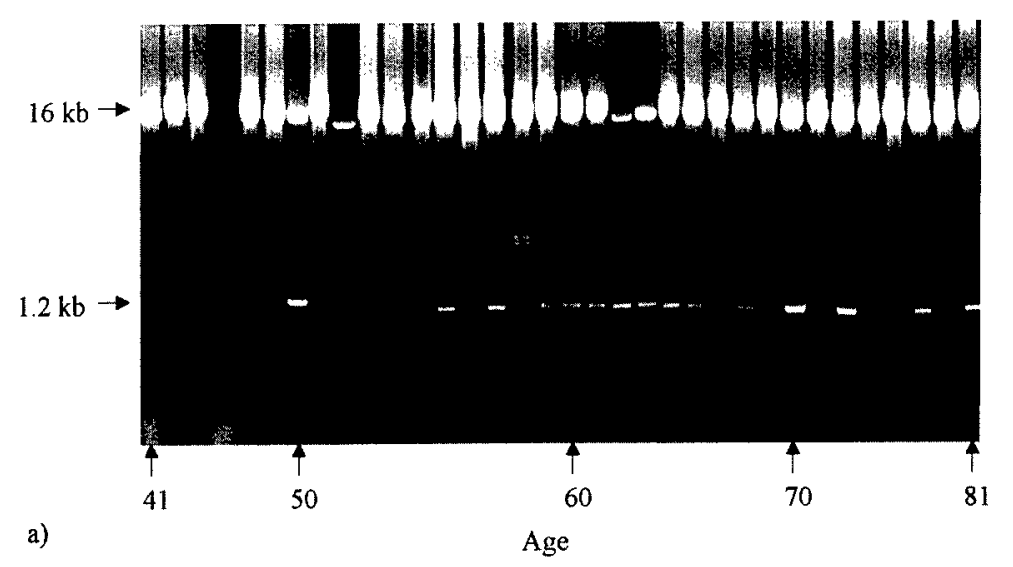

b)
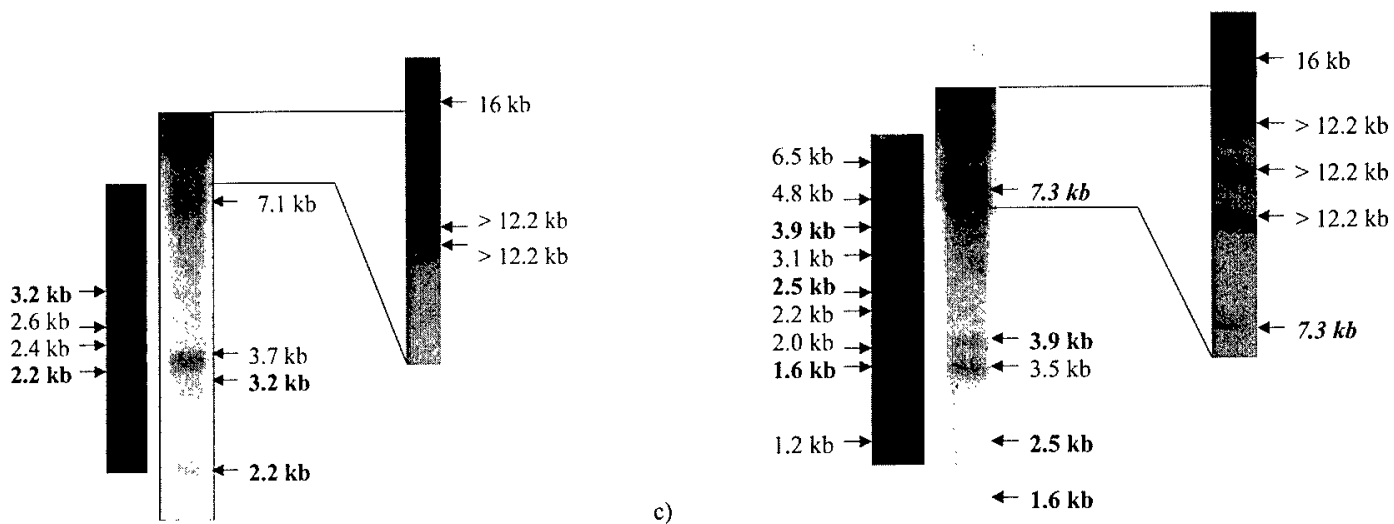

Fig. 1. (a) Composite gel of 34 prostate mtDNA LXPCRs. Samples are shown in order of increasing age from left to right beginning with age 41 (lane 1) and ending with age 81 (lane 34) (Note: Not all ages are accounted for). Older prostates have more mtDNA deletions seen here as an increased number of lower molecular weight bands. (b), (c) LXPCR (left) and two Southern blots of DNA from a 47 year old and a 79 year old, respectively. Note that the second Southern blot was run longer in order to separate the high MW bands (lines indicate area of magnification in second Southern blot). MW's in bold are common to both LXPCR and Southern blot. MWs in bold that are italicized are included to indicate the same bands between the two Southern blots. Also note that no $1.2 \mathrm{~kb}$ band is visualized in (b) but is visualized in the older sample (c).

and 1X Buffer - 3 (Boehringer Mannheim Expand Long Template PCR System; cat \#1681 834) was added to each LXPCR reaction tube. One ball of Ampliwax 50 (Perkin Elmer; cat \#N808-0150) was added to each tube and heated to $80^{\circ} \mathrm{C}$ for $3 \mathrm{~min}$ to melt the wax. The $20 \mu \mathrm{l}$ top phase was then added to each tube and consisted of a solution of $100 \mathrm{ng}$ of molecular DNA in water. The following LXPCR protocol was then followed:

1. $94^{\circ} \mathrm{C}$ for $2 \mathrm{~min}$;

2. $94^{\circ} \mathrm{C}$ for $10 \mathrm{~s}$;

3. $68^{\circ} \mathrm{C}$ for $10 \mathrm{~min}(2$ and 3 for 35 cycles);
4. $72{ }^{\circ} \mathrm{C}$ for $10 \mathrm{~min}$;

5. Hold at $4{ }^{\circ} \mathrm{C}$.

\subsection{Product visualization}

LXPCR products were resolved by horizontal electrophoresis using 1\% TAE Seakem agarose gels. Twenty $\mu 1$ of each sample was run for approximately $2 \mathrm{~h}$ at $160 \mathrm{~V}$.

\subsection{Quantification of mtDNA deletions}

Mitochondrial DNA deletions were quantified by 


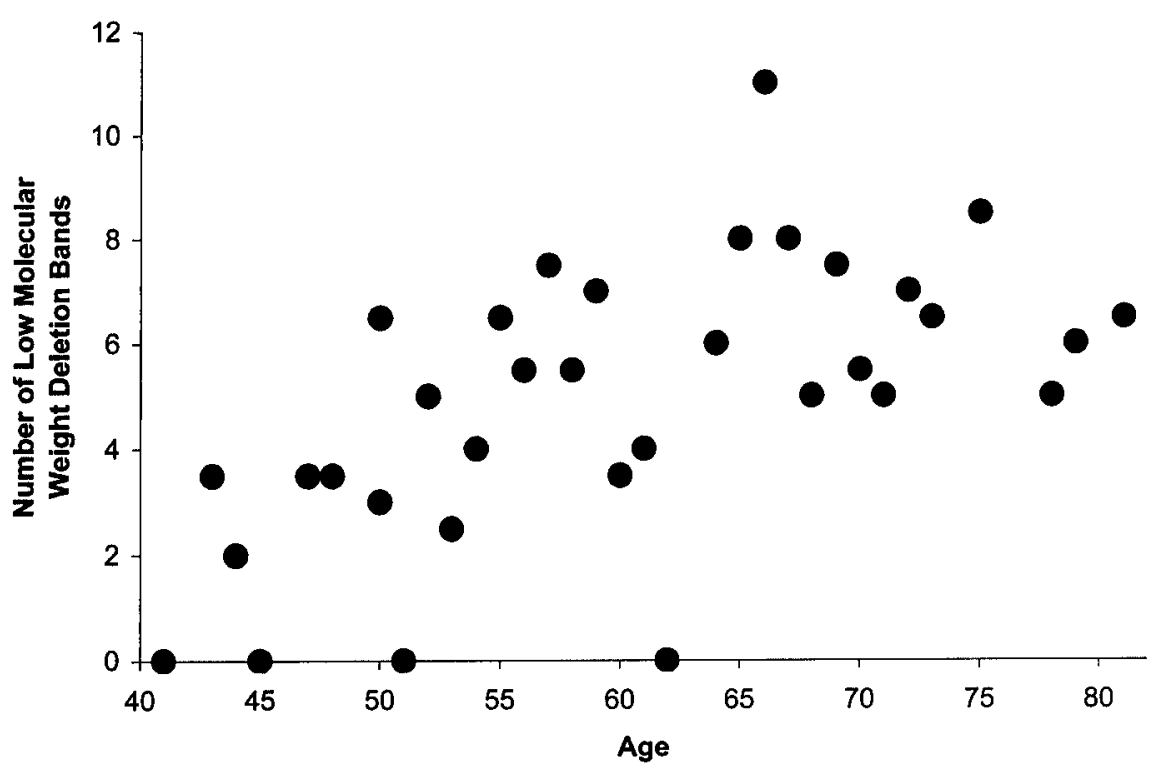

Fig. 2. The average number of large deletions (excluding the prominent $1.2 \mathrm{~kb}$ band) for each specimen shown versus age. The values shown reflect averages from the total counts of two independent observers.

manual count of all low molecular weight bands $(<16 \mathrm{~kb})$ by two independent observers. Data gathered were averaged to establish final values. In addition, the prominent $1.2 \mathrm{~kb}$ band was scored as present or absent.

\subsection{Southern analysis}

The full length mitochondrial genome was isolated and purified using a Boehringer Mannheim Agarose Gel DNA extraction kit (cat \#1 696 505) and labeled for use as a probe in Southern blots with a Roche DIG DNA labeling kit (cat \#1 175 033). Five mg of total genomic DNA was digested overnight with BamHI and run on $0.8 \%$ TAE Seakem agarose gels. Following denaturation and depurination, DNA was transferred to nylon membranes, hybridized with the labeled PCR-generated whole mtDNA probe and visualized using the DIG DNA system (Boehringer Mannheim).

\section{Results}

Fig. 1(a) is a composite gel of the 34 prostate mtDNA LXPCR samples. The youngest individuals (beginning with age 41 ) are located on the left and the oldest individuals (up to age 81) are on the right. There is a qualitative increase in the average number of low molecular weight bands $(<16 \mathrm{~kb})$ while moving from left to right on the gel indicating an increase in low molecular weight, deleted mitochondrial molecules as the age of the prostate specimen increases. Thus, LXPCR amplification of the mitochondrial genome shows that low molecular weight, deleted mtDNA molecules are more common in the older malignant prostate.

Quantitative analysis of the 34 samples revealed that $31(91 \%)$ contained at least one large deletion of the mitochondrial genome. The most consistent deletion was the loss of approximately $14.8 \mathrm{~kb}$ visualized as the $1.2 \mathrm{~kb}$ band in Fig. 1(a). This band was detected in $38 \%$ of men in their $40 \mathrm{~s}, 55 \%$ of men in their $50 \mathrm{~s}$, and $100 \%$ of men age 60 and older. Additional deletions of varying molecular weight were seen in most samples with increasing number of deleted molecules observed with advanced age. Fig. 2 shows the relationship between age and the average number of low molecular weight bands detected. Men in their $40 \mathrm{~s}$ had an average of 1.25 additional deletions detected while men in their $70 \mathrm{~s}$ had an average of 5.9 additional deletions as calculated by two independent observers. 
Fig. 1(b) shows an LXPCR (left) and two separate Southern blots from a 47 year old subject. These findings indicate that the bands detected by mtDNA amplification are not PCR artifact and confirm the existence of large deletions in the mitochondrial genome using a non-amplified method of detection. As expected PCR shows a preferential amplification of low molecular weight bands while Southern analysis preferentially visualizes higher molecular weight bands. However, multiple bands appear in both assays indicating that these are actual molecules and not simply PCR artifact. PCR remains a more sensitive assay for detecting mtDNA deletions while Southern analysis adds specificity to the evaluation. Fig. 1(c) is a similar look at a 79 year old. The same findings were noted in this older individual, but an increase in band number (as compared to Fig. 1(b)) was also found by both LXPCR and Southern blotting indicating an increase in deletions in older men.

\section{Discussion}

Mitochondrial DNA mutations occur in a wide variety of cancers and may have utility in the detection of cancer (Fliss et al., 2000). Indeed, some authors have implied that mitochondrial genome instability is so common and the enrichment of mutation in cancer so significant that some mutations probably confer a selective or replicative advantage to those cells that have acquired such mutations (Bianchi et al., 2001). Others have suggested that mtDNA mutations may enhance the toxicity of anti-cancer treatments (Hochhauser, 2000). Thus, the existence of mtDNA mutations in cancer may impact diagnosis and treatment and may be important in understanding the progression of some cancers.

From the results of our work, we conclude that mtDNA deletions occur in the malignant prostate and greater numbers are observed in the older malignant prostates than the younger malignant prostates. In particular, the $14.8 \mathrm{~kb}$ deletion is common, becoming universal in persons in their 60's and older. These findings are consistent with findings of other groups in different tissue types (Lee et al., 1994; Melov et al., 1995, 1997).

As all of our specimens contained cancer, it is possible that malignant transformation effects the accumulation of mtDNA deletions, though this was not tested in this study. Additional studies comparing young and old benign prostates would provide an interesting comparison, though such an analysis is beyond the scope of the present study.

These observations are also consistent with the fact that cellular oxidative stress increases over time (Sohal and Sohal, 1991). As these mitochondrial mutations increase, it is probable that dysfunction of translated mitochondrial proteins leads to a further increase in reactive oxygen due to defective oxidative phosphorylation and electron transport. This increase in reactive oxygen leads to more deletions in the mitochondrial genome establishing a self-perpetuating cycle with an ever-increasing oxidative challenge placed on the cell. Thus, it is possible that these deletions are not only a marker for aging, but also a cause of aging. By accumulating an ever-increasing number of deleted mtDNA molecules, the mitochondria of a cell continue to produce more reactive oxygen byproducts to damage cellular constituents.

\section{Acknowledgements}

We would like to thank Pinar Coskun for assistance with the LXPCR protocol, Dr Jonathan Simons and the Winship Cancer Institute and the Emory University School of Medicine for the funding of this project.

\section{References}

Ames, B.N., 1989. Endogenous DNA damage as related to cancer and aging. Mutat. Res. 414, 41-46.

Bianchi, N.O., Bianchi, M.S., Richard, S.M., 2001. Mitochondrial genome instability in human cancers. Mutat. Res. 488, 9-23.

Fliss, M.S., Usadel, H., Caballero, O.L., Wu, L., Buta, M.R., Eleff, S.M., Jen, J., Sidransky, D., 2000. Facile detection of mitochondrial DNA mutations in tumors and bodily fluids. Science 287 , 2017-2019.

Fraga, C.G., Shigenaga, M.K., Park, J.W., Degan, P., Ames, B.N., 1990. Oxidative damage to DNA during aging: 8-hydroxy-2'deoxyguanosine in rat organ DNA and urine. Proc. Natl. Acad. Sci. USA 87, 4533-4537.

Harman, D., 1956. Aging: a theory based on free radical and radiation chemistry. J. Gerontol. 11, 298-300.

Hochhauser, D., 2000. Relevance of mitochondrial DNA in cancer. Lancet 356, 181-182.

Lee, H.C., Pang, C.Y., Hsu, H.S., Wei, Y.H., 1994. Differential accumulation of $4977 \mathrm{BP}$ deletion in mitochondrial DNA of 
various tissues in human ageing. Biochim. Biophys. Acta 1226, $37-43$.

Melov, S., Shoffner, J.M., Kaufman, A., Wallace, D.C., 1995. Marked increase in the number and variety of mitochondrial DNA rearrangements in aging human skeletal muscle. Nucleic Acids Res. 23 (20), 4122-4126.

Melov, S., Hinerfeld, D., Esposito, L., Wallace, D.C., 1997. Multi- organ characterization of mitochondrial genomic rearrangements in ad libitum and caloric restricted mice show striking somatic mitochondrial DNA rearrangements with age. Nucleic Acids Res. 25 (5), 974-982.

Sohal, R.S., Sohal, B.H., 1991. Hydrogen peroxide release from mitochondria increases during aging. Mech. Ageing Dev. 57, 187-202. 


\title{
Isolation and characterization of the major form of human $M U C 18 \mathrm{cDNA}$ gene and correlation of MUC18 over-expression in prostate cancer cell lines and tissues with malignant progression
}

\author{
Guang-Jer Wu ${ }^{a}{ }^{*}$, Mei-Whey H. Wu ${ }^{a}$, Shur-Wern Wang ${ }^{a}$, Zhong Liu ${ }^{a}$, Pengpeng Qu ${ }^{a}$, \\ Qiong Peng ${ }^{\mathrm{a}}$, Hsiuchin Yang ${ }^{\mathrm{a}}$, Vijay A. Varma ${ }^{\mathrm{b}, \mathrm{d}}$, Qi Carrie Sun ${ }^{\mathrm{c}}$, John A. Petros ${ }^{\mathrm{b}, \mathrm{c}, \mathrm{d}}$, \\ So Dug Lim ${ }^{\mathrm{b}}$, Mahul B. Amin ${ }^{\mathrm{b}}$ \\ "Department of Microbiology and Immtnology, Emory University School of Medicine, Atlanta, GA 30322, USA \\ ${ }^{\mathrm{b}}$ Department of Pathology and Laboratory Medicine, Emory University School of Medicine, Atlanta, GA 30322, USA \\ ${ }^{\mathrm{C}}$ Department of Urology, Emony University School of Medicine, Atlanta, GA 30322, USA \\ 'The Atlanta VA Medical Center, Emory University School of Medicine, Atlanta, GA 30322, USA
}

Received 1 May 2001; received in revised form 3 September 2001 ; accepted 24 September 2001

Received by T. Sekiya

\begin{abstract}
Ectopical expression of huMUC18, a cell adhesion molecule in the immunoglobulin gene superfamily, causes a non-metastatic human melanoma cell line to become metastatic in a nude mouse system. To determine if MUC18 expression correlates with the development and malignant progression of prostate cancer, we investigated differential expression of human MUC18 (huMUC18) in normal prostate epithelial cells, prostate cancer cell lines, and prostatic normal and cancer tissues. We cloned and characterized the human $M U C 18$ (huMUC18) cDNA gene from three human prostate cancer cell lines and three human melanoma cell lines. The cDNA sequences from the six human cancer cell lines were identical except differences in one to five nucleotides. The deduced amino acid sequences of the longest ORF were 646 amino acids that were identical in these cDNAs except for one to three amino acid residues. The amino acid sequences of all our huMUC18 cDNA genes are similar to that cloned by other group (GenBank access \#M28882) except differences in the same seven amino acids. We conclude that huMUC18 cDNA gene reported here represents the gene product from a major allele. The MUC18 mRNA and protein was expressed in three metastatic prostate cancer cell lines (TSU-PR1, DU145, and PC-3), but not in one non-metastatic prostate cancer cell line (LNCaP.FGC). The expression of huMUC18 in these four cell lines is positively related to their extent of in vitro motility and invasiveness and in vivo metastasis in nude mice. HuMUC 18 protein was also expressed at high levels in extracts prepared from tissue sample sections containing high grade prostatic intraepithelial neoplasia (PIN), but weakly expressed in extracts prepared from cultured primary normal prostatic epithelial cells and the normal prostate gland. Immunohistochemical analysis showed that huMUC18 was expressed at higher levels in the epithelial cells of high-grade PIN and prostatic carcinomas, and in cells of a perineural invasion, a lymph node, and a lung metastases compared to that in normal or benign hyperplastic epithelium (BPH). We therefore conclude that MUC18 expression is increased during prostate cancer initiation (high grade PIN) and progression to carcinoma, and in metastatic cell lines and metastatic carcinoma. Increased expression of MUC18 is implicated to play an important role in developing and malignant progression of human prostate cancer. Furthermore, the lacking of predominant cytoplasmic membrane expression of MUC18 appeared to correlate with malignant progression of prostate cancer. (C) 2001 Elsevier Science B.V. All rights reserved.
\end{abstract}

Keywords: Human MUC18 cDNA sequence; mRNA and protein expression; Prostate cancer cell lines; Normal and malignant prostatic tissues; Inmunohistochemistry

\footnotetext{
Abbreviations: BCIP, 5-bromo-4-choloro-3-indolyl-1-phosphate; CAM. Cell adhesion molecule; cDNA, complementary DNA; DAB, 3,3'-diaminobenzidine tetrachloride; dATP, deoxy-adenosine-triphosphate; FPLC, fast-performance liquid chromatography; GAPDH, glyceraldehye- $3^{\prime}$-phosphosphate dehydrogenase; GST, glutathione-S-transferase; huMUC18, human MUC18; HRV-3C protease, 3C protease of human rhinovirus type 14; IPTG, isopropyl $\beta$-Dthiogalactopyranoside; Mel-CAM, melanoma cell adhesion molecule; moMUC18, mouse MUC18; NBT, nitroblue tetrazolium; ORF, open reading frame; PCR, polymerase chain reaction; PMSF, phenylmethyl-sulfonyl fuoride; RT-PCR, reverse transeription PCR; X-gal, 5-bromo-4-chloro-3-indolyl- $\beta$-D-galactopyranoside

* Corresponding author. Tel.: + 1-404-727-0296; fax: +1-404-727-3659

E-mail address:wu@microbio.cmory.edu (G.-J. Wu).
} 


\section{Introduction}

Prostate cancer is now the most commonly diagnosed malignancy and the second leading cause of death in American males (Landis et al., 1999). Growth of primary prostatic carcinoma may be slow, often extending over decades. The majorities of histologically localized prostatic carcinomas remain sub-clinical and never require treatment. However, prostatic carcinomas in some patients rapidly metastasize, killing the patients in a few months to several years after initial diagnosis. The mechanism by that localized prostatic carcinomas become metastatic remains unknown. Conversion of a localized prostatic carcinoma into a metastatic cancer very likely requires multiple mutations (Carter et al., 1990). Mutations or altered expression of genes, which encode cell-adhesion molecules (CAMs), various matrix metalloproteinases (MMPs), tissue specific inhibitors of MMPs (TIMPs) (Tang and Honn, 1994-1995), heparanase (Toyoshima and Nakajima, 1999), RhoC (Clark et al., 2000), and any gene products that alter cytoskeleton structure, and cellular motility and invasiveness (Clark et al., 2000), can directly affect the initial phase of metastasis by increasing the motility and invasiveness of tumor cells.

Aberrant expression of different CAMs is correlated with the progressiveness of many tumors (Pignatelli and Vassey, 1994; Tang and Honn, 1994-1995). For example, loss of Ecadherin has been documented in high-grade prostate carcinoma (Umbas et al., 1992). Knowledge of the role of other CAMs in the malignant progression of prostate cancer is limited (Sciavolino and Abate-Shen, 1998). Human MUC18 (huMUC18, Mel-CAM, CD146), a CAM in the immunoglobulin gene superfamily, originally found to be expressed on the surface of human malignant melanoma cells Lehmann et al., 1987), has been reported to mediate metastasis of human melanoma cells in immunodeficient mice (Xie et al., 1997; Schlagbauer-Wadl et al., 1999). MUC18 is not expressed in most normal tissues (Shih et al., 1998), but it may be immunohistochemically detectable in normal breast epithelium (Shih et al., 1997), basal cells in bronchial epithelium (Shih et al., 1997), smooth muscle cells (Lehmann et al., 1987; Sers et al., 1994), endothelial cells (Sers et al., 1994; Bardin et al., 1996), activated T-cells (Pickl et al., 1997), and cerebellum (Shih et al., 1998). The expression of MUC18 in other cancers and significance of its role in developing other cancers has not been thoroughly studied except as a possible tumor suppressor in breast cancer (Shih et al., 1997).

In this report, we used RT-PCR analysis, Northern blot analysis, immunological methods, and immunohistochemistry to compare the expression of MUC18 in prostate cancer cell lines and pre-cancerous and malignant prostatic tissues with that in the normal/benign prostate. We present the first evidence of MUC18 expression in prostate cancer cell lines and cancerous tissues. This work has been presented (Wu et al., 1999).

\section{Materials and methods}

\subsection{Cell lines and cell culture conditions}

The human melanoma cell lines SK-Mel-28, A375, and WM115 from the American Type Culture Collection (ATCC) (Rockville, MD) were maintained in Eagle's minimum essential medium (EMEM) (GIBCO/BRL/Life Technologies, Grand Island, NY) supplemented with sodium pyruvate and $10 \%$ fetal bovine serum. Human prostate cancer cell lines, DU145, LNCaP.FGC, and PC-3 were also from the ATCC. TSU-PR1 was originally established by $\mathrm{Dr}$ T. Iizumi, at Japan (Iizumi et al., 1987) and was obtained from Dr John T. Isaacs, Baltimore, MD. DU145 was maintained in RPMI1640 medium, or EMEM supplemented with sodium pyruvate, and $10 \%$ fetal bovine serum (GIBCO/BRL/Life Technologies, Grand Island, NY, or Mediatech/Cellgro, Herndon, VA). TSU-PR1 was maintained in RPMI1640 supplemented with $10 \%$ fetal bovine serum. LNCaP.FGC was maintained in a modified RPMI 1640 that contained $20 \mathrm{mM}$ HEPES, $10 \mathrm{mM} \mathrm{NaPyr}-$ uvate, and $2 \%$ glucose, and supplemented with $10 \%$ fetal bovine serum. PC-3 was maintained in F-12K medium/ RPMI1640 (1:1) with $10 \%$ fetal bovine serum. Normal primary human prostatic epithelial cells (Clonetics, San Diego, CA) were maintained in prostate epithelial cell basal serum-free medium supplemented with growth factors (bovine pituitary extract, hydrocortisone, hEGF, epinephrine, transferrin, insulin and retinoic acid). Normal prostate gland (\#96-10B) was snap frozen in liquid nitrogen, and kept at $-70^{\circ} \mathrm{C}$. A frozen neoplastic tissue section ( $\mathrm{S} 98$ 3066\#3) from prostatectomy and a lymph node metastasis (S99-1731A) were obtained at the Atlanta VA Medical Center. Paraffin-embedded melanoma and normal and cancerous prostate tissue sections were from the tissue archive of the Emory University Hospital.

\subsection{Total cellular RNA and poly $(A)+R N A$}

Total RNA from cell lines was prepared according to the one step acid-guanidinium thiocyanate-phenol-chloroform extraction procedure (Chomczyuski and Sacchi, 1987). Poly(A) + RNA was purified from total RNA by a single passage through an oligo(dT)-cellulose column (Yang et al., 2001).

\subsection{Cloning of huMUCI8 cDNA gene}

RT-PCR was used to amplify the huMUC18 cDNA gene (Kawasaki, 1990). A reverse transcription kit (Promega, Madison, WI) was used (Yang et al., 2001). In brief, the first strand cDNA was synthesized in a standard $\mathrm{RT}$ reaction (20 $\mu 1$ ), which contained $1 \mu \mathrm{g}$ of $\operatorname{poly}(\mathrm{A})+\mathrm{RNA}$ from three human melanoma cell lines (SK-Mel-28, A375, and WM115) and three prostate cancer cell lines (DU-145, PC3 , and TUS-PR 1) as template and other necessary ingredients, at $42-48^{\circ} \mathrm{C}$ for $1 \mathrm{~h}$. The intact huMUC18 cDNA was 
amplified for 30 cycles in a PCR reaction, which contained the first strand cDNA, two specific primers BF-1 (27-mer, CTCGGGATCCATGGGGCTTCCCAGGCT) and ER6a (25-mer, TCGGGGCTAATGCCTCAGATCGATG) that were designed from the published sequence (Lehmann et al., 1989), and other necessary ingredients, at an annealing temperature of $65-66^{\circ} \mathrm{C}$. The PCR products were cloned to the pGEM-T or pGEM-T easy vector (Promega). Positive (white) clones were first identified by restriction enzyme analysis (New England Biolabs, Beverly, MA, or American Allied Biochemicals, Aurora, $\mathrm{CO}$ ) and then further characterized by rapid DNA sequencing. DNA sequencing was carried out by using an ABI prism dye terminator cycle sequencing ready reaction kit (Perkin-Elmer) with various huMUC18 specific primers in an automated ABI 373XL sequencer.

\subsection{Computer program for comparison of nucleotide and amino acid sequences}

Lasergen program was used for calculating the isoelectric point, determination of secondary structure, hydrophilicity, and surface probability and antigenic index, and for alignment of cDNA and amino acid sequences of the huMUC18 cDNA genes from six different cell lines.

\subsection{Semi-quantitative RT-PCR analysis and Northern blot analysis of huMUC18 $\mathrm{mRNA}$}

Total RNAs from a human melanoma cell line (SK-Mel28) and four prostate cancer cell lines were used for semiquantitative RT-PCR analysis of the abundance of huMUC18 mRNA in each cell line (Yang et al., 2001).

The mRNA level in various cell lines was also determined by Northern blot analysis (Ausubel et al., 1987) with minor modifications (Yang et al., 2001). Purified poly (A) + RNA was used for the analysis. The probe was a partial huMUC18 cDNA fragment (1936 bp), which was RT-PCR-amplified from poly(A) + RNA of SK-Mel-28 cells using two specific primers, BF1 and ER4 (28-mer, CTCGAATTCTACAAGTTCGGTCTTACGA), at an annealing temperature of $62^{\circ} \mathrm{C}$.

\subsection{Production of recombinant huMUC18 protein in E. coli for making antibodies}

The subfragment (from amino acid \#211 to 376) of the huMUC18 cDNA was cloned in-phase into an expression vector, pGEX-6p-1, of a GST-fusion protein expression system (Amersham Pharmacia Biotech). The huMUC18 cDNA subfragment was inserted at the C-terminus of the glutathione-S-transferase(GST) coding region that was used as an affinity-tag. The protein was over-expressed by induction with IPTG in E. coli K-12 strain BL-21. The bacteria cell pellet from 3-liter of culture was washed and suspended in $40 \mathrm{ml}$ of ice-cold PBS (10 $\mathrm{mM} \mathrm{Na} 2 \mathrm{HPO}_{4}, 1.8 \mathrm{mM}$ $\mathrm{KH}_{2} \mathrm{PO}_{4}, 2.7 \mathrm{mM} \mathrm{KCl}$, and $140 \mathrm{mM} \mathrm{NaCl}, \mathrm{pH} \mathrm{7.3)}$ and then lysed with a pre-chilled French pressure cell at 800 psi. A standard purification protocol in the Pharmacia manual was followed with minor modifications (Yang et al., 2001). The purified recombinant huMUC18 protein was about $22 \mathrm{kDa}$. The purity of the protein was characterized by SDS-PAGE (8-10\% polyacrylamide gel). Six mg of the purified recombinant huMUC18 protein was sent to Lampire Biological Laboratories (Pipersville, PA) for immunization of three chickens to make polyclonal antibodies.

The anti-MUC18 antibody titres were determined by ELISA assay using the purified recombinant MUC18 protein as the antigen. Eggs collected during the period of the highest serum antibody titres were used for purification of chicken IgY (Lampire Biol. labs.).

\subsection{Western blot analysis}

Cell extracts from various cultured cell lines were prepared by directly lysing the monolayer tissue cells with the Western blot lysing buffer (Ausubel et al., 1987), added an anti-proteolytic cocktail that included $1 \mathrm{mM}$ benzamidine, $0.5 \mathrm{mM}$ PMSF, and $1 \mu \mathrm{g} / \mathrm{ml}$ each of antipain, leupeptin, chymostatin, and pepstatin A (Sigma Chemical Co.), boiled, and kept frozen until use.

The extract from a frozen normal prostate gland $(6 \mathrm{~g})$ was prepared by first dicing with a sharp razor blade, adding 14 $\mathrm{ml}$ of cold PBS containing the anti-proteolytic cocktail, and finally homogenized in an anaerobic tissue processor (BT Scientific Tech., San Diego, CA). Then, one volume of the extract was mixed with three volumes of Western blot lysis buffer, added the anti-proteolytic cocktail, boiled, and kept frozen until use.

The extract of a frozen section of a neoplastic prostate gland tissue $(0.8 \mathrm{~g})$ was prepared by homogenization (for 50 strokes) with four volumes of cold PBS containing the antiproteolytic cocktail using a Dounce Homogenizer (type A pestle). The large particulate membrane fraction was separated from the soluble fraction of the homogenates by low speed centrifugation $(2000 \times g$ for $10 \mathrm{~min})$. Both the soluble fraction and the large particulate membrane fraction were mixed with three volumes of the Western blot lysis buffer, boiled, and kept frozen until use. The extract of a human lymph node metastasis $(0.2 \mathrm{~g})$ was prepared by homogenization with four volumes of $\mathrm{RB}$ buffer $(10 \mathrm{mM}$ Tris- $\mathrm{HCl}$, $\mathrm{pH} 7.5,10 \mathrm{mM} \mathrm{NaCl}, 1.5 \mathrm{mM} \mathrm{MgCl}_{2}$, and $7 \mathrm{mM}$ 2-mercaptoethanol) containing the anti-proteolytic cocktail for 10-15 $s$ at the \#10 setting in a Polytron homogenizer (Brinkmann Instruments, Westbury, NY) in a cold room. The homogenate was added $1 / 3$ volumes of the $4 \times$ Western blot lysis buffer, mixed, boiled, and kept frozen until use.

The protein contents of all extracts were determined by the Bradford method (Bio-Rad Laboratories, Hercules, CA) and confirmed by SDS-PAGE after staining with Buffalo Black. Human MUC18 protein expression in cellular extracts prepared above was determined by the standard 
procedure of Western blot analysis (Ausubel et al., 1987). The protein in the gel was electrophoretically transferred to a nitrocellulose membrane (RPN\#303W, Hybond-C pure, Amersham Pharmacia Biotech.) using the Bio-Rad MiniBlot-Cell. Then the membrane was blotted with 5\% nonfat milk overnight. The first antibody was chicken IgY antirecombinant human MUC18 protein (middle fragment) (20-30 $\mu \mathrm{l}$ per $7 \mathrm{ml}$ ). In the competition experiment, the reaction with the first antibody was carried out in the presence of one $\mu \mathrm{g}$ of purified recombinant MUC18. The second antibody was alkaline phosphatase-conjugated goat (Promega) or rabbit (Chemicon International Inc., Temecula, CA) anti-chicken $\operatorname{IgY}$ antibodies $(2 \mu \mathrm{l}$ per $7 \mathrm{ml})$. $\mathrm{BCIP/NBT}$ (Promega) was used as the chromogen.

\subsection{Immunostaining of culture cells}

Cells were cultured on a sterile cover glass (22-mm sq., Corning Labware and Equipment) or Poly-D-lysine coated 8-well culture slide (Becton Dickinson Labware, Bedford, MA) and processed as described (Ausubel et al., 1987). Cells were fixed with $4 \%$ paraformaldehyde for cytoplasmic membrane staining, acetone for staining intracellular membranes and structures, or 4\% paraformaldehyde plus $100 \%$ methanol for cytoplasmic staining. The primary antibody used was a chicken anti-huMUC18 antibody (1/175 for immunofluorescence or $1 / 500$ for $\mathrm{DAB}$ staining). The secondary antibody was fluorescein-conjugated rabbit antichicken IgG (1/100) (AP162F, Chemicon) or biotinylated rabbit anti-chicken antibodies (1/500, G2891, Promega).

\subsection{Immunohistochemistry of paraffin-embedded tissue sections}

Paraffin-embedded tissue sections from the tissue archive of Emory University Hospital were used. A human malignant melanoma tissue section was used as an external positive control for the immunohistochemical staining. The human tissue sections of a few melanoma cases, 32 cases of prostatic adenocarcinoma (thirty-two prostatectomy specimens) and five metastasis to various organs were deparaffinized, and rehydrated, and immunohistochemically stained as described (Ausubel et al., 1987).

\subsection{Determination of in vitro motility and invasiveness of cultured cells}

Determination of in vitro motility and invasiveness of cells was carried out as described (Passaniti et al., 1992).
In the antibody blocking experiments, $150 \mu \mathrm{g} / \mathrm{ml}$ of chicken anti-huMUC18 antibodies was added to the suspended cells and incubated for 15-30 min before seeding the cells to the top wells of the transwell system.

\section{Results}

\subsection{The sequence of huMUC18 cDNA}

To initiate the studies, we obtained the human MUC18 ( $h u M U C 18$ ) cDNA by RT-PCR amplification of poly(A) + RNA from human melanoma SK-Mel-28 cells that express high levels of MUC18 protein (Lehmann et al., 1989). Primers BF-1 and ER6a, which were designed from the published huMUC18 cDNA sequence (Lehmann et al., 1989), were used to amplify a fragment of 1957 bp that contained the entire coding sequence. We found that the nucleotide sequence of the huMUC18 cDNA, which was cloned from human melanoma cell line SK-Mel-28, was identical to the published $h u M U C 18 \mathrm{cDNA}$ sequence except 17 nucleotides (Lehmann et al., 1989). The longest ORF of our huMUC18 cDNA encoded 646 amino acids. In contrast, the longest ORF of the huMUC18 cDNA by Lehmann et al. (1987) encoded only 603 amino acids. Several stretches of assigned amino acid sequence between the two ORFs were very different, suggesting that this discrepancy could be due to an alternatively spliced form of huMUC18 mRNA or simply due to sequence errors. To differentiate these two possibilities and resolve the discrepancy, we amplified and determined the sequences of the $h u M U C 18$ cDNAs from five additional human cancer cell lines: two human melanoma cell lines, A375 and WM115, and three prostate cancer cell lines, DU-145, PC-3, and TSU-PR1. Table 1 shows the similarity and difference of nucleotide sequences of the huMUC18 cDNA from six human cancer cell lines. We found that the nucleotide sequences of the $h u M U C 18$ cDNAs from all five human cancer cell lines were identical to that from the human melanoma cell line SK-Mel-28 except one to five nucleotides (Table 1). Since they all have the longest ORF of 646 amino acids, we concluded that our sequence was correct. However, the nucleotide sequence of our huMUC18 cDNA was similar to the huMUC18 cDNA sequence later deposited in GenBank by the same group (access \#N28882) (also with the longest ORF of 646 amino acids) except for 13 nucleotides, which were due to four point mutations, one deletion, and one insertion (Table 1). From this result, we concluded that the previously published huMUC18 cDNA sequence had

Fig. 1. The nucleotide sequence and deduced amino acid sequence of huMUC18 cDNA (A) and predicted physical structures of huMUC18 protein (B). (A) shows the nucleotide sequence and the deduced amino acid sequence of huMUC18 cDNA. Poly(A) + RNA purified from total RNA of the human melanoma cell line, SK-Mel-28 was used for RT-PCR amplification. The PCR products were cloned, and plasmid DNAs of positive clones identified by restriction enzyme analysis and then characterized by rapid DNA sequencing as described in Section 2. Lasergen and GCG program was used for deduction of amino acid sequences from the nucleotide sequence of the cloned huMUC18 cDNA. (B) shows the predicted secondary structures, hydrophilicity, surface probability, and antigenic index of the protein. The Lasergen program was used. 
1. ATG GGG CTT CCC AGG CTG GTC TCC GCC TTC TTE CTC CCC GCC TCC TCC TGC TGT CCT COC GTC GCG GGT GTG CCC GGA GAG GCT GAG CAG Mat Giy leu pro arg lou val Cy Ala the leu lou Ala Ala cys Cys Cys Cys Pro arg val Ala Gly val pro Gly Glu Ala Glu Gla

91 CCT GCG CCT GAG CTG GTG GAG GTG GM GTG GOC NOC ACA COC CJT CTG MG TEC GEC CTC TOC CAG TOC CM GOC MA CTE MOC CAT GTC

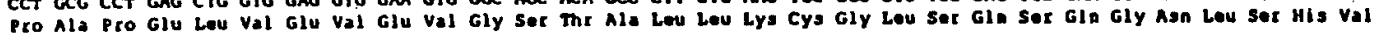

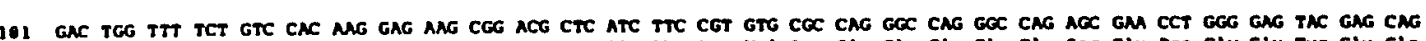

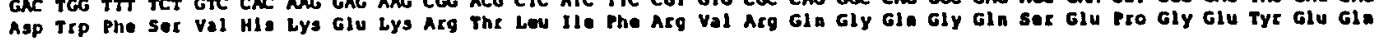

271 CGG CTC AGC CTC CAG GAC AGA GGG GCT ACT CTG GCC CTG ACT CM GTC AOC CCC CAA GAC GAG COC ATC ITC TTÓ TEC CAG GEC MAG CAC

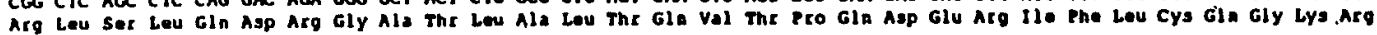

361 CCT CGG TCC CAG GAG TAC COC ATC CAG CTC COC GTC TAC MM GCT CCE GAG GAG CCA AAC ATC CAG GTC AMC COC CTG GOC ATC CCT GTG

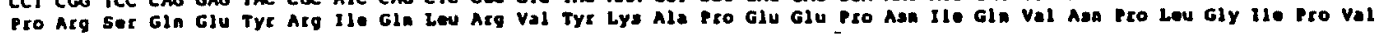

451 MAC AGT AAG GAG CCT GAG GAG GTC GCT ACC TGT GTA GGG AGG AAC GGE TAC COC ATT CCT CAM GTC ATC TEG TAC MAG MAT GEC CEG CCT

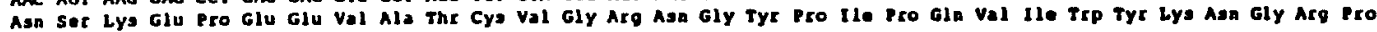

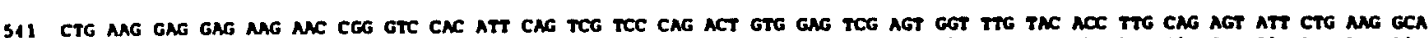

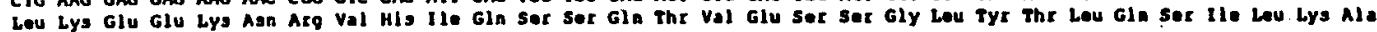

631 CAG CTG GTT AM GM GNC AM GAT GCC CAG TTT TAC TGT GAG CTC AMC TAC COG CTO CCC AGT GGG ANC CAC ATG MAG GAG TCC AOG GM

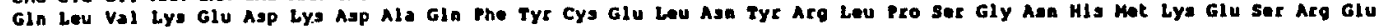

721 GTC ACC GTC CCT GTT TTC TAC CCEG ACA GM AM GTG TGG CTG GM GTG GAG CCC GTE GGA ATG CTG AMG OM GOG GAC CEC GTE GM ATC

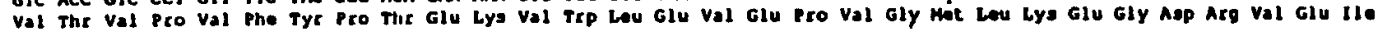

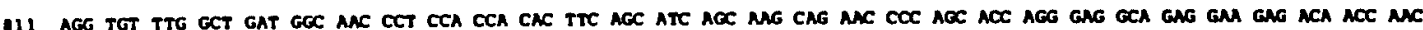
Aro Cys Leu Ala Asp Giy Agn Pro Pro Pro HIa pho ser lle ser lya Gin Aan Pro ser the Arg Glu Ala Glu Glu Glu thr The Asn

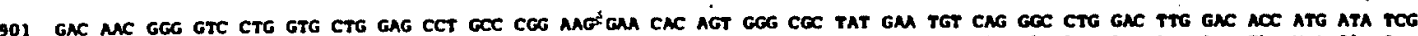

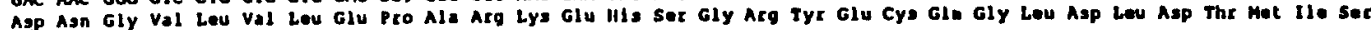

991 CTE CTE AGT GM CCA CAG GM CTA CTE GTG MA TAT GTG TCT GAC GTC CGA GTE AGT COC GCa CCC CCT GAG AGA CAG GM GOC ACC ACC

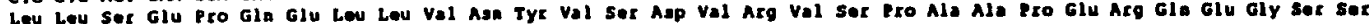

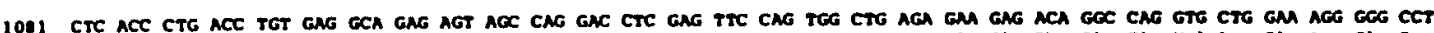

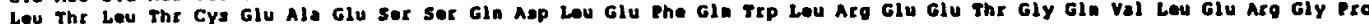

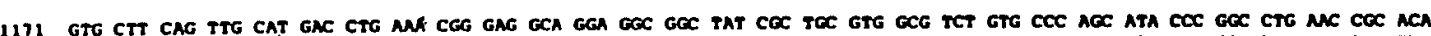

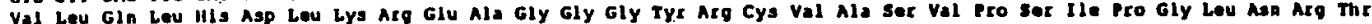

1261 CAC CTG GTC NAC GTG CCC ATT TTT GCC CCC CCT TGG ATG GCA TTC ANG GAG AGG AAG GTG TCG GTE AM GAG MT ATE GTC TTE MAT CTC

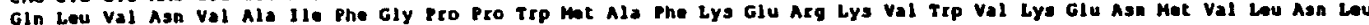

1351 TCT TGT GM GCG TCA GGC CAC CCC CGO COC ACC ATC TCC TGG AMC GTC MAC GOC ACE GCA AGT GM CM GAC CM GAT CCA CAG CGA GTC

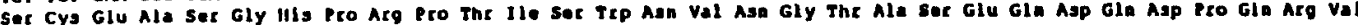

1442 CTG AGC ACC CTG MAT GTC CTC GTE ACC CCG GNG CTG TTG GAG ACA GGT GTT GM TGC ACG GOC TCC AMC GAC CTG GCC MM ANC MOC ACC

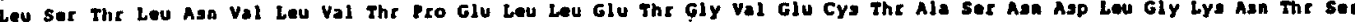

1531 ATC CTC TTC CTG GAG CTG GTC AAT ITA ACC ACC CTC ACA CCA GAC TCC AAC ACA ACC ACT GOC CTC ACC ACT TCC ACT GCC AGT CCT CAT

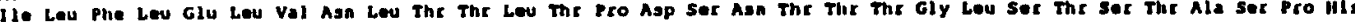

1622 ACC AGA GCC AMC AGC ACC TCC ACA GAG AGN AMG CTG CCG GAG CCG GAG AOC CGG GOC GTC GTC ATC GTE GCT GTE ATT GTC TCC ATC CTC

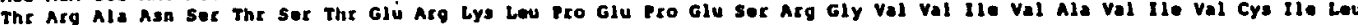

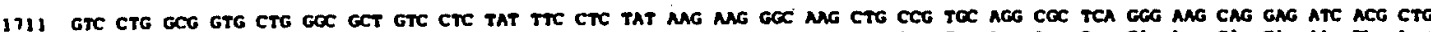

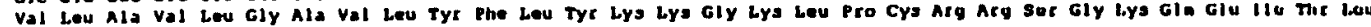

1101 CCC CCG TCT COT MAG AOC GM CTT GTA GTT GM GTT MG TCA GAT AAG CTC CCA GM GAG ATE GCC CTC CTG CAG GOC ACC ACC GOT GAC

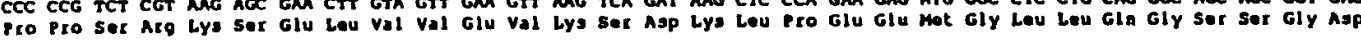
o

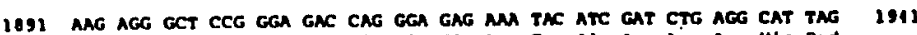
Lys Arg Ala pro Gly Asp Gin Gly Glu hys Tye llo Asp lieu Arg III End

$\begin{array}{lllllllllllllllllllllllllllll}25 & 50 & 75 & 100 & 125 & 150 & 175 & 200 & 225 & 250 & 275 & 300 & 325 & 350 & 375 & 400 & 125 & 450 & 475 & 500 & 525 & 550 & 575 & 600 & 625\end{array}$

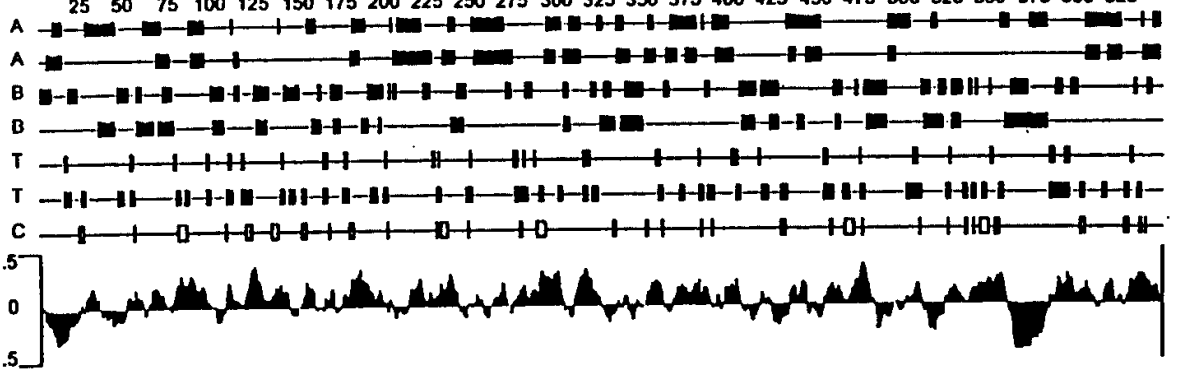

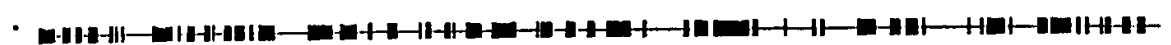

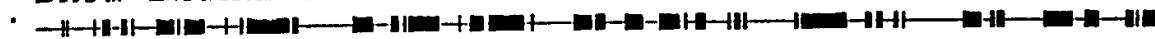

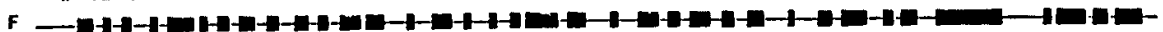

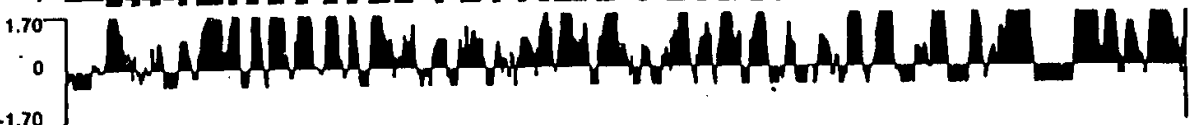
$-1.70$

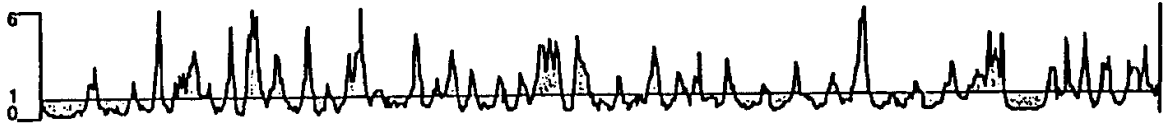

- Ajpha, Reglons - Ganier-Robson Alpho, Regions - Chou-Fasman a Bots, Reglons - Gamier-Robson Bela, Rogions - Chou-fasman - Tum. Regions - Ganier-Robson - Turn, Regions - Chou-Fasman oColl, Reglons - Gander-Robsan

Eydrophilicily Plol - Kyle-Doolitlle

Apto, Amphipatric Regions - Eisenberg - Bola, Amphipathic Reglons - Eisenberg Iflexiblo Regions - Karplus-Sctulz

- Antigenic indax - Jameson-Wolf

o Surface Probalitily Plot - Emint 
Table 1

Sequence variation of huMUC18 cDNAs isolated from three human prostate cancer and three human melanoma cell lines

\begin{tabular}{|c|c|c|c|c|c|}
\hline Nucleotide \#/amino acid \#/cell lines & $\begin{array}{l}\text { SK-Mel-28 DU145 } \\
\text { PC-3 (majority) }\end{array}$ & A 375 & WM115 & TSU-PR1 & $\begin{array}{l}\text { Human Melanoma JJ (1994) } \\
\text { GenBank \#M28882 }\end{array}$ \\
\hline N\#228/AA\#V76V & 226GTG & & & GTA & \\
\hline N\#384/AA\#I128I & $382 \mathrm{ATC}$ & ATT & & & \\
\hline $\begin{array}{l}\text { N\#965, 967, 968, 970/AA\#G322A, } \\
\text { L323W, D324N }\end{array}$ & 964GGCCTG GAC & & & & GCCTGGAAC \\
\hline N\#1 148/AA\#G383D & $1147 \mathrm{GGC}$ & & & & GAC \\
\hline N\#1257/AA\#R419R & $1255 \mathrm{CGC}$ & CGG & & & \\
\hline N\#1272, 1273/AA\#N424K, V425L, & 1270AACGTG & & & & AAGCTG \\
\hline N\#1471/AA\#E491K & 1472GAG & & AAG & AAG & \\
\hline N\#1582/AA\#T528A & $1582 \mathrm{ACA}$ & & & GCA & \\
\hline N\#1800/AA\#L600L & $1798 \mathrm{CTG}$ & & & CTA & \\
\hline N\#1817/AA\#S606T & $1816 \mathrm{AGC}$ & & & & $\mathrm{ACC}$ \\
\hline N\#1877/AA\#G626D & $1876 \mathrm{GGC}$ & & & GAC & \\
\hline
\end{tabular}

four mistakes in nucleotide sequence (Lehmann et al., 1989) and was not an alternatively spliced form (Table 1).

The amino acid sequences of the longest ORF deduced from the $h u M U C 18$ cDNA sequences of SK-Mel-28 are shown in Fig. 1A. The amino acid sequences deduced from the huMUC18 cDNA sequences of the three human cancer cell lines, DU145, PC-3, and A375, were identical to that of SK-Mel-28 (Fig. 2). The two point mutations in the huMUC18 cDNA of A375 were due to neutral mutation and thus did not alter any amino acid assignment. As also shown in Fig. 2, the amino acid sequences deduced from the huMUC18 cDNA sequence of WM115 were identical to that of SK-Mel-28 except one amino acid residue, which was due to one point mutation. However, only three of the five nucleotide differences in the cDNA of TSU-PR1, $228 \mathrm{G} \rightarrow \mathrm{A}, 1471 \mathrm{G} \rightarrow \mathrm{A}, 1582 \mathrm{~A} \rightarrow \mathrm{G}, 1800 \mathrm{G} \rightarrow \mathrm{A}$, and $1877 \mathrm{G} \rightarrow \mathrm{A}$ (Table 1), resulted in encoding different amino acids: E491K, T528A, and G626D (Table 1 and Fig. 2). The huMUC18 cDNA from three prostate cancer cell lines and from three human melanoma cell lines encodes 646 amino acids and consistently shows the same seven amino acid residues different from that of the huMUC18 cDNA deposited in the GenBank by Johnson's group (GenBank access \# M28882) (Hm18Meljj.pro in Fig. 2 ). Since the sequence of the $h u M U C 18$ cDNA gene from all six human cancer cell lines are nearly identical, we concluded that the huMUC18 cDNA gene identified in this report was very likely derived from a major allele, whereas the huMUC18 cDNA (GenBank access \#M28882) from Johnson's group appeared to be from a minor allele.

The deduced huMUC18 protein has a predicted isoelectric point of 5.72 (with a charge of -9.82 at $\mathrm{pH} 7$ ).

The amino acid sequence fulfills all criteria proposed for membership of huMUC18 in the immunoglobulin gene superfamily (Lehmann et al., 1989). The extracellular portion of huMUC1 8 consists of five repetitive domains, with a high homology to each other and to immunoglobulin-like domains. Each domain consists of approximately 54-85 amino acid residues and contains two appropriately spaced cysteines as well as conserved residues flanking the cysteines. An algorithm to predict protein secondary structure indicates predominantly $\beta$-strand structure in each of the five domains, and hydrophilicity analysis predicts two major hydrophobic domains (from amino acid \#1-\#28 and from \#559-\#583) (Fig. 1B). The 28 amino acid residues of the $5^{\prime}$ hydrophobic domain (from amino acid \#1-\#28) contain the secretory signal peptide sequence and the 24 amino acid residues of the $3^{\prime}$ hydrophobic domain (from \#559-\#583) are characteristic of a transmembrane domain. In addition, there are eight putative glycosylation sites (Asn$\mathrm{X}$-Ser/Thr) located in the extracellular region of the molecule. The last 64 amino acid residues constitute the cytoplasmic tail that contains potential phosphorylation sites for various protein kinases (Sers et al., 1993).

\subsection{Expression of MUC18 $\mathrm{mRNA}$ in four prostate cancer cell lines}

The expression of huMUC18 mRNA in four different prostate cancer cell lines was analyzed by semi-quantitative RT-PCR. Fig. 3 shows that the RT-PCR amplified fragment, $1957 \mathrm{bp}$, which contained the complete coding sequence of MUC18, was detectable in the total cellular RNAs of three prostate cancer cell lines, DU-145, PC-3, and TSU-PR1, but not in that of one cell line, LNCaP.FGC. Among the three huMUC18-expressing cell lines, the highest level of huMUC1 8 mRNA was expressed in DU-145, and the lowest

Fig. 2. Comparison of amino acid sequences of huMUC18 cDNA from three human melanoma cell lines and three human prostate cancer cell lines with that from the human melanoma of Johnson's group (GenBank access \#M28882) (from top to bottom, SK-Mel-28, A375, WM1 15, DU-145, PC-3, TSU-PR1, and human melanoma by Johnson's group). Identical amino acids are shown by shade and different ones by open boxes. 


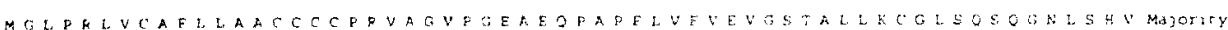

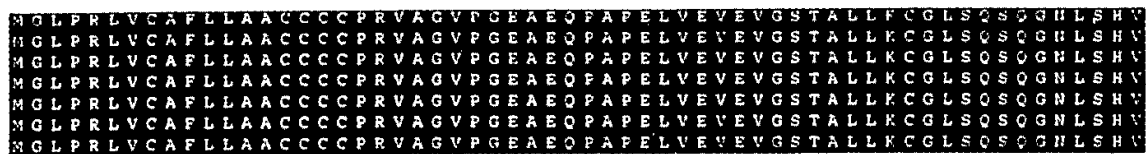

STYGj, SRO

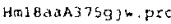

Hmi

Hmi Basugum pro

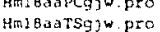

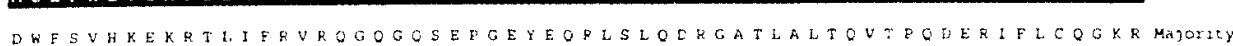

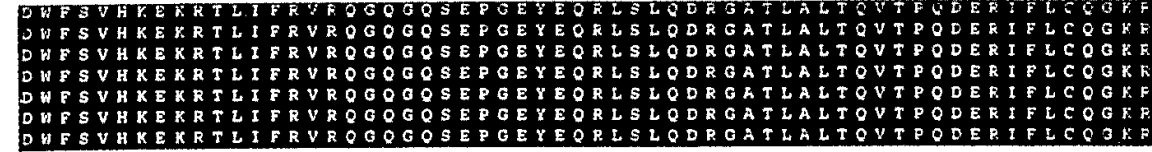

\section{ihmisdaskgjw. PRo \\ Hmiadinj75gjw. pro \\ HmiscainMgjw.pro \\ RmisapCojw pro \\ Hmla \\ Hml ta aMel j j pro}

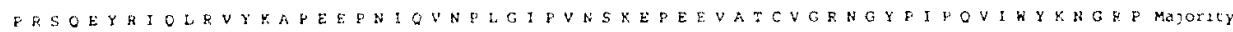

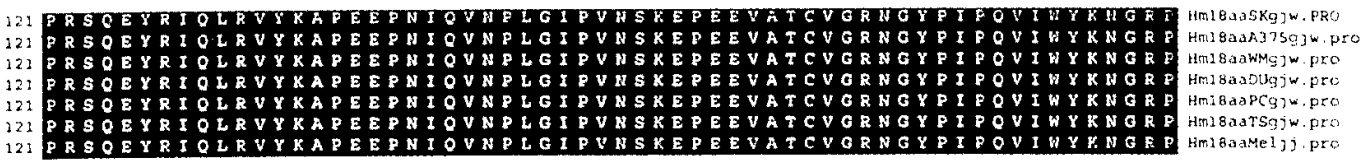

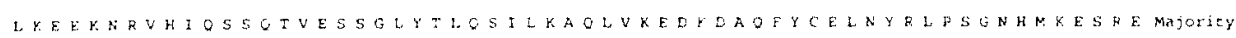

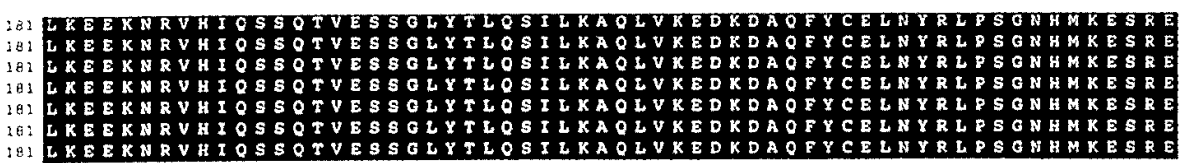

HentBuaskgjw. PRo

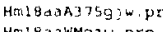

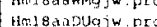

Hm1 вaspcajw pro

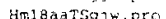

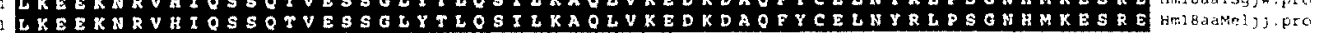

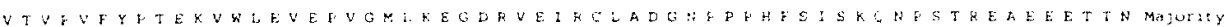

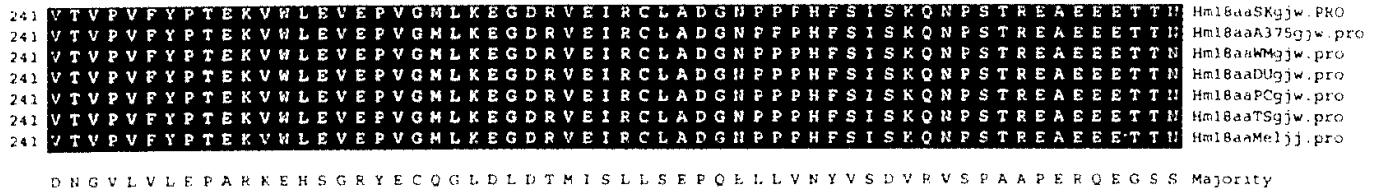

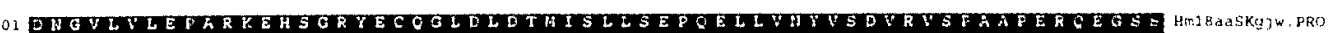

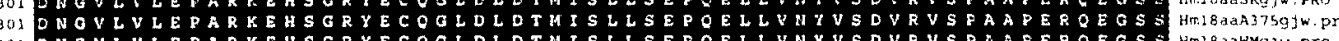

301 ONGVLVLEPARKEHSGRYECOOLDLDTHISLLSEPOELLVNY VSDVRVSPAAPEROEGSS HFIBATMGJWTRO

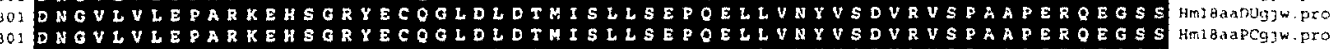

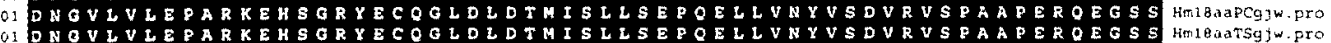

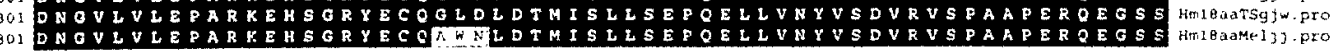

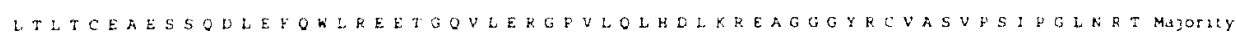

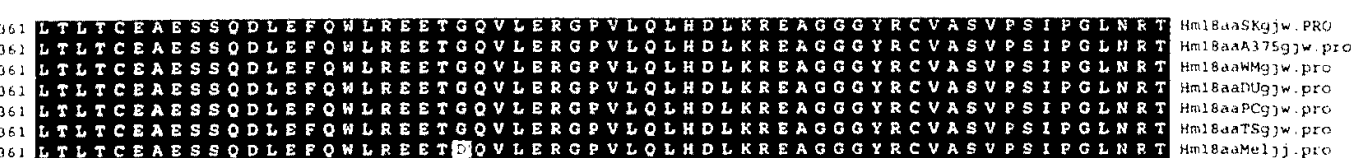

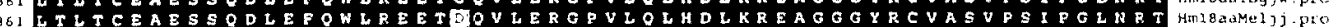

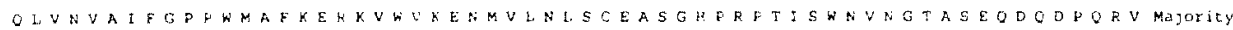

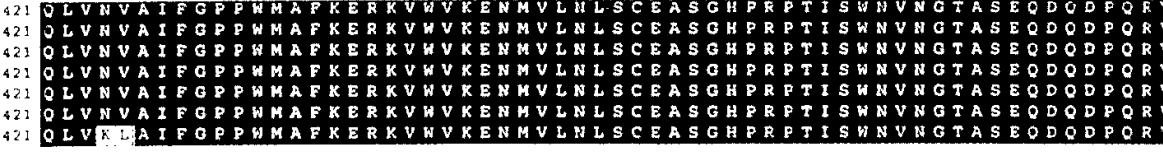

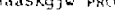

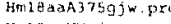

Hiritasimgjw.pro

Hinlatabugjw pro

Hen $\theta_{\text {ana }}$

Him:Batatsgjw. pro

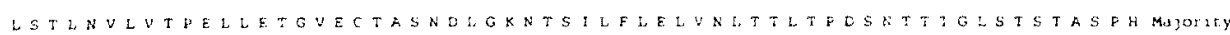

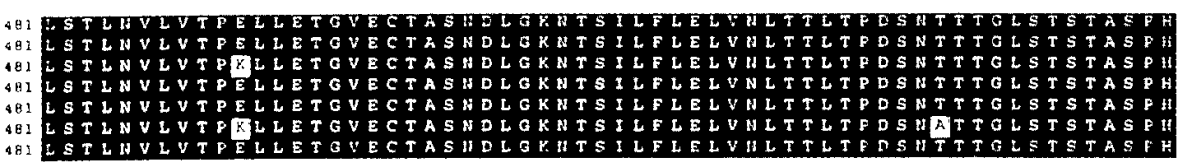

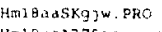

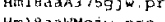

Himl 1aakMMgjw-pro

Hmisaatsgy pro

TRANSTSTERXLPERESFGVVIVAVIVEILVLAVLOAVLYFJYKKGYLPCRRSGKOEITL MAJOYIT

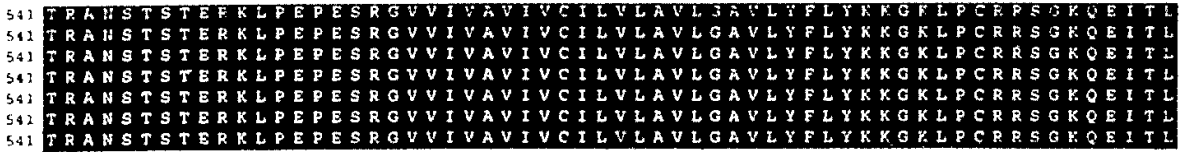

Him? Barskg jw. PRei Hrn 18aAA3759jw.pro

Hmi Baabligiw pro

imi basbligfw. pro

HmisaaPC9jw pro

ppSPKSELVVEVKSDKLEEEMGLLOGSGGEKRAPGDGGEKYIDLR

Hmitankel jy. pro

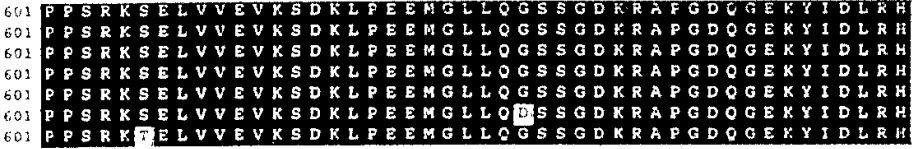

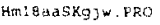

HmL8a:A375kjw.pro

Himlsathimgju. pro

Him18anDUgjw. pr

HmisatapCg)w pro

HmlBaitsgjw pro

Hor 1 datage jj pro 

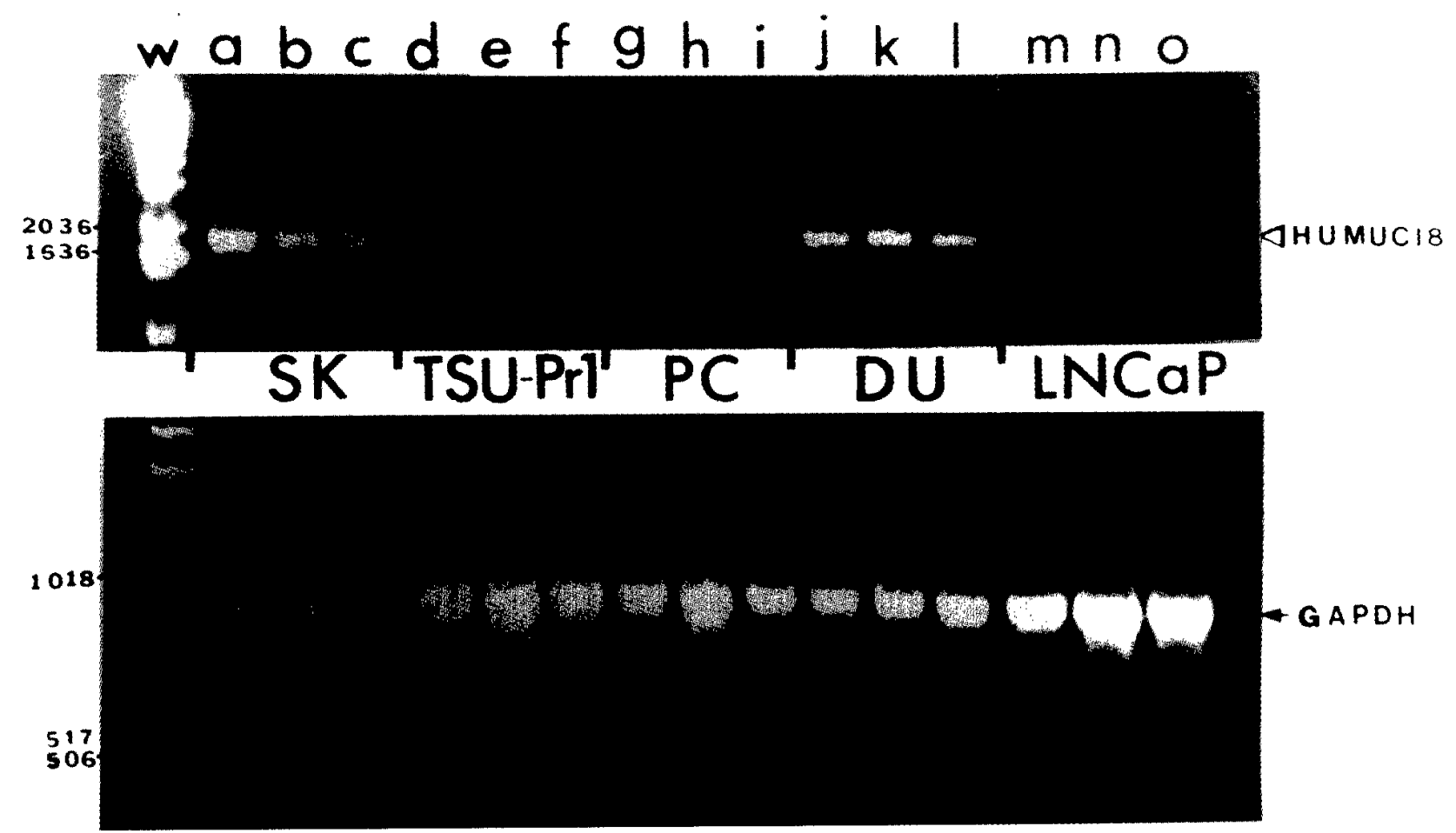

Fig. 3. Expression of huMUC18 mRNA in four human prostate cancer cell lines. Semi-quantitative RT-PCR analysis was used to determine the expression of huMUC18 mRNA in four prostate cancer cell lines, TSU-PR1, DU145, PC-3, and LNCaP.FGC. $3.5 \mu \mathrm{g}$ of total RNA from each cell line was used for reverse transcription. The cDNA was subsequently used for PCR amplification of huMUC18 cDNA when BF1 and ER6a were used as the primer pair, as described in Section 2. The cDNA was also used for PCR amplification of human GAPDH cDNA when HRMF1 (CGCCTGGTCACCAGGGCTGC) and HRMR2b (CACCACCCTGTTGCTGTAGCC), which were designed according to the published human, rat, and mouse GAPDH cDNA sequences (Yang et al., 2001) and used as the primer pair, at an annealing temperature of $59^{\circ} \mathrm{C}$. Triplicate PCR reactions were carried out. (Top panel) The RT-PCR amplified huMUC18 cDNA (1957 bp) from each cell line (indicated with an open arrowhead and HuMUC18). Lanes a-c show the PCR-amplified band from the RNA of the human melanoma SK-Mel-28 cell, lanes d-f show that from the human prostate cancer cell line TSU-PR1, lanes g-i from the PC-3 cell line, lanes $j-1$ from the DU-145 cell line, and lanes $\mathrm{m}-\mathrm{o}$ from the LNCaP.FGC cell line. The molecular weight markers used were the $1 \mathrm{~kb}$ ladders (GIBCO/BRL, Life Technology) (lane MW). (Bottom panel) The expression of human GAPDH RNA in each RNA sample, which was used as an internal control (indicated with an arrow and GAPDH). The same cDNA from the above RT reaction was also used for PCR amplification of human GAPDH cDNA using a GAPDH-specific primer pair, HRMF1 and HRMR2b.

level in TSU-PR1. The presence of huMUC18 mRNA in the three prostate cancer cell lines that had positive RT-PCR results was confirmed by Northern Blot analysis (data not shown). Similar to the RT-PCR result, the huMUC18 mRNA was not detectable in LNCaP.FGC cells by the Northern blot analysis. The approximate size of huMUC1 8 mRNA was about $3.3 \mathrm{~kb}$ in all three human prostatic cancer cell lines that express MUC18, similar to the huMUC18 mRNA expressed in a human melanoma cell line, SK-Mel-28, as shown by Northern blot analysis (data not shown). Thus we concluded that huMUC18 mRNA is expressed in three prostate cancer cell lines (DU-145, PC-3, and TSU-PR1), but not in one prostate cancer cell line (LNCaP.FGC).

\subsection{Expression of huMUC18 protein in prostate cancer cell lines}

We expressed the middle fragment of the huMUC18 protein in a GST-fusion protein expression system and used the purified recombinant protein $(22 \mathrm{kDa})$ for production of chicken polyclonal antibodies. The recombinant protein may not be glycosylated in bacteria since the molecular weight of the purified recombinant protein is very similar to the predicted value, although a potential $\mathrm{N}$ glycosylation site is present in this region of the protein. The IgY polyclonal antibodies purified from eggs of the immunized chickens were able to react with the $22 \mathrm{kDa}$ recombinant protein (data not shown). Furthermore, the anti-MUC18 antibodies were also found to react with the huMUC18 protein in the protein lysate of human melanoma SK-Mel-28 cells, suggesting that the antihuMUC18 IgY antibodies were able to recognize epitopes present in the recombinant huMUC18 fragment as well as epitopes present in the protein expressed in the human melanoma cells (Fig. 4, lane a). The anti-huMUC18 IgY antibodies have a high specificity since they cross-react poorly with the phylogenically related mouse MUC18 protein, which has a $76.2 \%$ amino acid sequence identity to the huMUC18 (Yang et al., 2001). The high specificity 


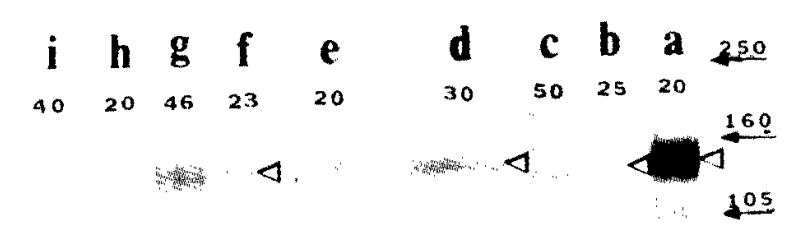

LNCaP PC-3 DU145 Tsu-PR1 SK 25

Fig. 4. Expression of huMUC18 protein in human prostate cancer cell lines. Western blot analysis was used to determine the huMUc 18 protein expression in the same four prostate cancer cell lines. Cell lysates from four cell lines were prepared and used for Western blot analysis, as described in Section 2. SK stands for cellular lysate prepared from human SK-Mel-28 cells (lane a), TSU-PR 1 for TSU-PR1 cells (lanes b,c), DU145 for DU145 cells (lanes d,e), PC-3 for PC-3 cells (lanes $f, g$ ), and LNCaP for LNCaP.FGC cells (lanes $\mathrm{h}-\mathrm{i}$ ). The number at the top of each lane indicates the amount of protein $(\mu \mathrm{g})$ loaded in each well. The huMUC 18 protein band is indicated with an open arrowhead.

of the antibodies was further supported by that the MUC18 band in all the human cancer cell line lysates as revealed in the Western blot analysis was completely competed in the presence of $1 \mu \mathrm{g}$ of purified recombinant huMUC18 protein (data not shown). Furthermore the MUC18 band was not detectable by substituting the anti-huMUC18 $\operatorname{IgY}$ with the pre-immunization chicken IgY. This antihuMUC18 IgY was used to detect the expression of huMUC18 protein in four prostate cancer cell lines. The huMUC1 8 protein was found to be highly expressed in DU145 and PC-3, and moderately expressed in TSU-PR1 (Fig. 4, lanes b-g). However, the huMUC18 protein was not expressed in the LNCaP.FGC cell line, as shown in Fig. 4 (lanes $\mathrm{h}-\mathrm{i}$ ). Thus we concluded that huMUC18 protein was expressed only in three prostate cancer cell lines, but not in one prostate cancer cell line. Since the differences in levels of MUC18 protein expression are similar to those found in the level of mRNA, the lack of expression of MUC18 in the LNCaP.FGC cell line was due to the absence of mRNA production in this cell line.

\subsection{Location of huMUC18 expression in the subcellular structures of human melanoma and prostate cancer cells}

Fig. 5A shows that huMUC18 was expressed on the cellular surface (cytoplasmic membrane) and Fig. 5B that it was also expressed in the cytoplasm, but not in the nuclei of the human melanoma cells SK-Mel-28. Fig. 5C shows that huMUC18 was also expressed in the cell-cell junctions between adjacent cells, perhaps via homotypic interaction mediated by heterophilic ligands (Sers et al., 1994). Fig. $5 \mathrm{D}, \mathrm{E}$ show that huMUC18 was expressed both in cellular membrane and in cytoplasm of DU-145 and TSU-PR I prostate cancer cells. HuMUC18 was also expressed in PC-3 cells, but not expressed in LNCaP.FGC cells (data not shown).
3.5. The in vitro motility and invasiveness of four human prostate cancer cell lines

Fig. 6A shows that the three cell lines DU-145, PC-3, and TSU-PR 1 that express huMUC18 had a higher motility in vitro than the one cell line, LNCaP.FGC that does not express huMUC18. Fig. 6B shows that the same three cell lines DU-145, PC-3, and TSU-PR1 that express huMUC18 also had a higher invasiveness in vitro than the one cell line, LNCaP.FGC that does not express huMUC18. Thus we concluded that the three huMUC18-expressing prostate cancer cell lines had a higher motility and were more invasive than the one cell line that does not express huMUC18. As also shown in Fig. 6, both motility and invasiveness of the three prostate cancer cell lines that express MUC18 were inhibited by anti-huMUC18 IgY, this indicates that MUC18
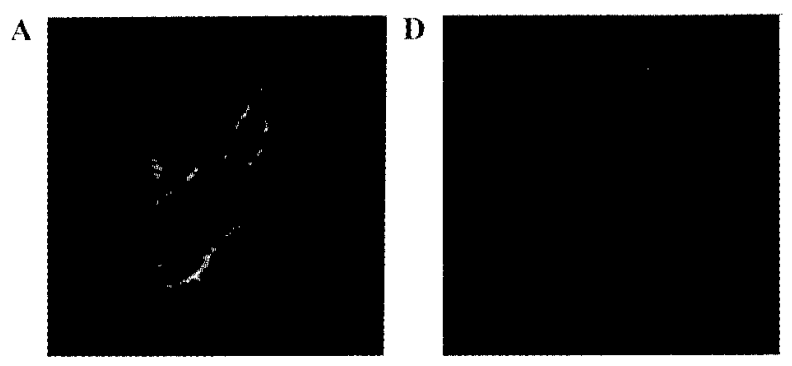

$\mathbf{B}$
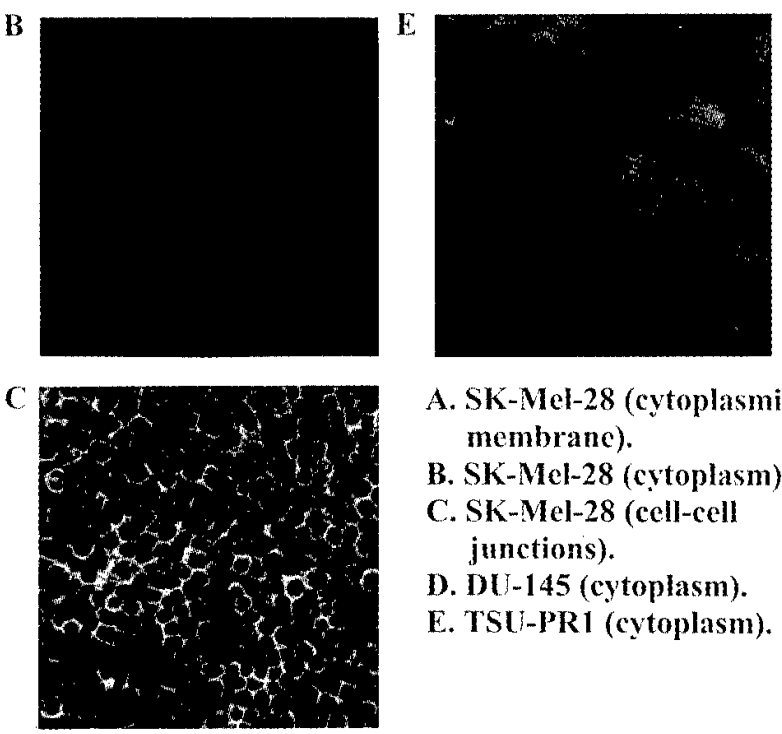

A. SK-Mel-28 (cytoplasmic membranc).

B. SK-Mel-28 (cytoplasm).

C. SK-Mel-28 (cell-cell junctions).

D. DU-145 (cytoplasm).

E. TSU-PR1 (cytoplasm).

Fig. 5. Immunofluorescence location of huMUC18 expression in the subcellular structures of human melanoma cell line SK-Mel-28 (A-C) and two prostate cancer cell lines, DU-145 (D) and TSU-PR1 (E). Cells were cultured on a sterile cover glass ( $22 \mathrm{~mm}$ sq., Corning Labware and Equipment) or Poly-D-lysine coated 8-well culture slide (Becton Dickinson Labware, Bedford, MA) and fixed with $4 \%$ paraformaldehyde (A,C, for cytoplasmic membrane staining only), acetone ( $\mathrm{B}$ and $\mathrm{E}$, for staining intracellular membranes and structures), or $4 \%$ paraformaldehyde plus $100 \%$ methanol (D, for cytoplasmic staining). The primary antibody used was chicken anit-huMUCI8 polyclonal antibodies $(1 / 175)$ and the secondary antibody $(1 / 100)$ was fluorescein-conjugated rabbit anti-chicken IgG (AP162, Chemicon International Inc., Temecula, CA). The fluoresceinstained cells were observed under a Confocal microscope. All pictures were at $630 \times$ magnification except $(C)$ at $250 \times$ magnification. 
expressed in these cell lines significantly contributes to these cellular behaviors.

\subsection{Differential expression of huMUC18 protein in normal prostatic epithelial Cells, normal prostate gland, and cancerous prostatic tissues}

To investigate the possible expression of MUC18 protein
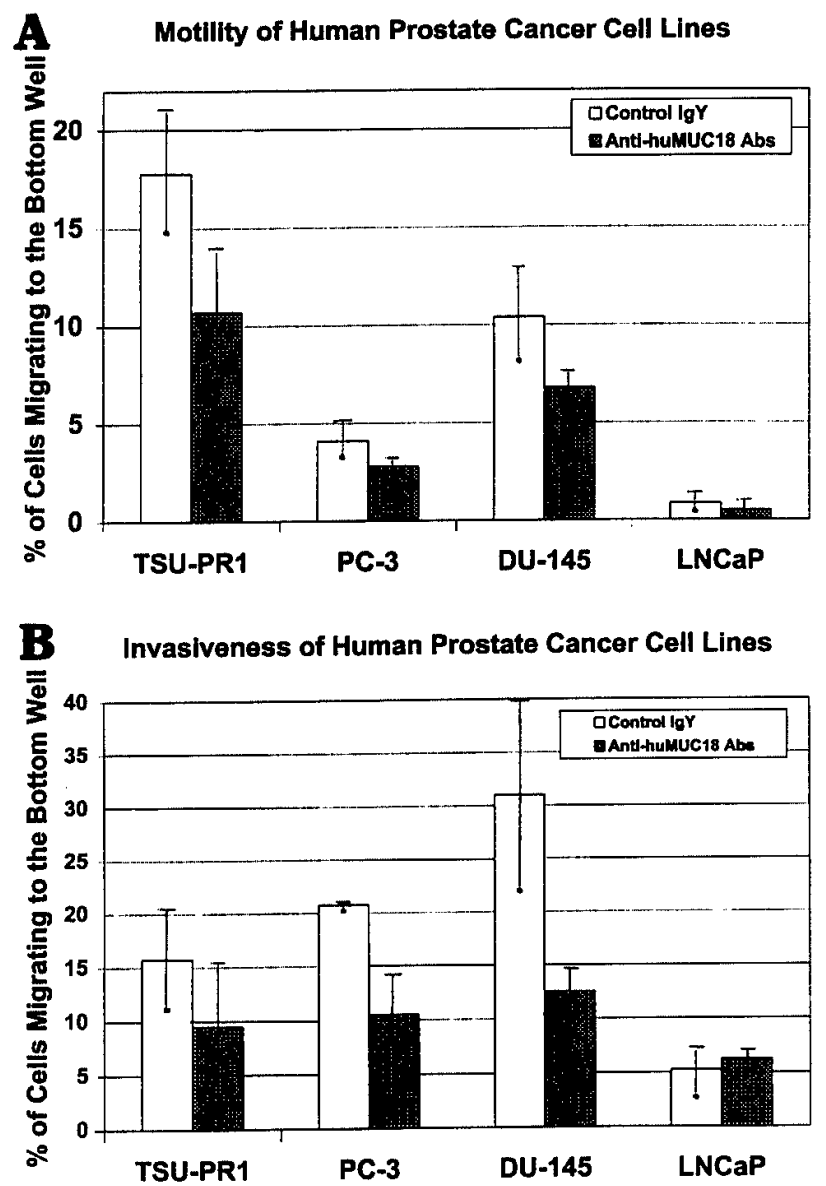

Fig. 6. The in vitro motility and invasiveness of four human prostate cancer cell lines. The motility and invasiveness of four prostate cancer cell lines were determined as described in Section 2 . For motility tests, $2 \times 10^{5}$ cells in $0.4 \mathrm{ml}$ of medium, containing $0.1 \%$ bovine serum albumin, were seeded to each top well insert ( $8.0 \mu \mathrm{m}$ pore size, Falcon \#35-3182) of the Boyden type transwell TC 12 well-plate (Falcon \#35-3503), after $12 \mathrm{~h}$ cells migrating to the bottom wells were trypsinized and counted. For invasiveness test, the same motility test was used except that pores of the membrane in the bottom of the top well ( $12 \mu \mathrm{m}$ pore size, Costar \#3403) were coated with $150 \mu \mathrm{g}$ of Matrigel (Collaborative Research /BD Sciences \# 40234C) in 65 $\mu \mathrm{l}$ medium, which was added to each of the top wells and allowed it to solidify in $37^{\circ} \mathrm{C}$ for at least $30 \mathrm{~min}$, before seeding of cells. Cells migrated to the bottom of the membrane were trypsinized and counted after $16 \mathrm{~h}$. (A) Shows the motility of the four prostate cancer cell lines, DU-145, PC-3, TSU-PRI, and LNCaP.FGC. (B) Shows the in vitro invasiveness of the same four cell lines of (A). Percentage of cells migrating to the bottom wells was indicated. Results are presented as the means of triplicate experiments. Standard deviations are also shown. The open bars show percentages of migratory cells treated with control chicken IgY and the filled bars those treated with anti-huMUC18 antibodies.

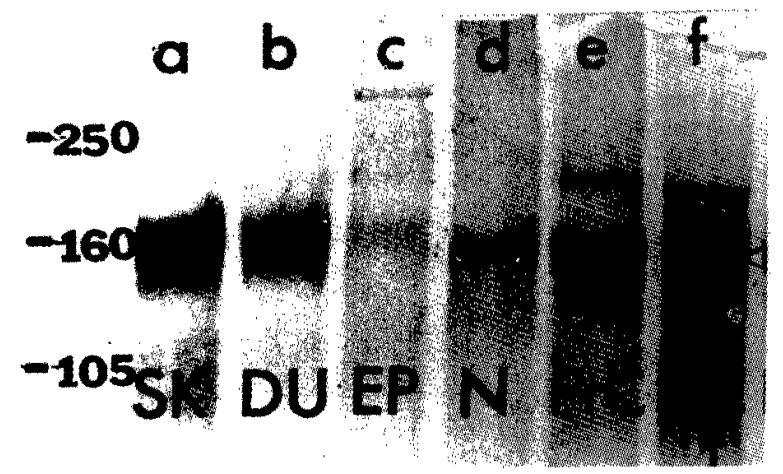

Fig. 7. Expression of huMUC18 protein in normal and cancerous prostatic tissues. Western blot analysis was used for determination of human MUC18 protein expressed in normal primary human prostatic epithelial cells (EP, lane $\mathrm{c}$ ), normal prostatic gland $(\mathrm{N}$, lane $\mathrm{d})$, and the prostate tissue sample of a patient with high grade PIN ( $\mathrm{PrC}$ and PrC-m in lanes e-f). Cellular lysates were prepared from these tissues as described in Section 2. The lysate prepared from the soluble fraction of the tissue with PIN is shown in ( $\operatorname{PrC}$, lane $\mathrm{e})$ and that from the large particulate membrane fraction of the same tissue in (PrC-m, lane f). Cellular extracts prepared from human SKMel-28 cells (SK, lane a) and from DU145 cells (DU, lane b) were shown as the positive controls. $20 \mu \mathrm{g}$ protein of each lysate was loaded per well. The arrowhead indicates the huMUC18 protein band.

in normal and cancerous prostatic tissues, cellular extracts were prepared from these tissues for Western blot analysis. Fig. 7 (lane d) shows that MUC18 protein was expressed at low levels in the extract from normal prostate glands. This could be due to the expression of MUC18 in endothelial cells of blood vessels or smooth muscle cells in the stroma (as was later seen in immunohistochemistry, Fig. 8), and thus it might not represent the normal expression of MUC18 in the luminal or secretory epithelial cells of the prostate. To support this prediction, cellular extracts were also prepared from cultured primary normal prostatic epithelial cells for the analysis. Fig. 7 (lane c) shows that huMUC18 protein antigen was very weakly expressed in these cultured normal prostatic epithelial cells. The very low level expression of MUC18 in these normal epithelial cells is possibly due to in vitro induced expression, since these primary cells were cultured in the presence of many growth factors and TPA. Thus the low level of MUC18 expression in these cultured normal prostatic epithelial cells might not reflect the normal cellular gene expression in vivo, since similar result was obtained from in vitro cultivated melanocytes (Yang et al., 2001) that normally do not express MUC18 (Shih et al., 1998).

In contrast, huMUC18 expression was increased in extracts prepared from prostatic tissues of a patient with prostatic intraepithelial neoplasia (PIN) at a similarly high level of that detected in the extract from a human melanoma cell line, SK-Mel-28, as shown in Fig. 7 (lanes e-f versus lane a). Notably, a higher level of MUC18 was detected in the large particulate membrane-enriched fraction than the soluble fraction of the same tissue section (Fig. 7, lane $\mathrm{f}$ versus lane e). From these results, we concluded that 


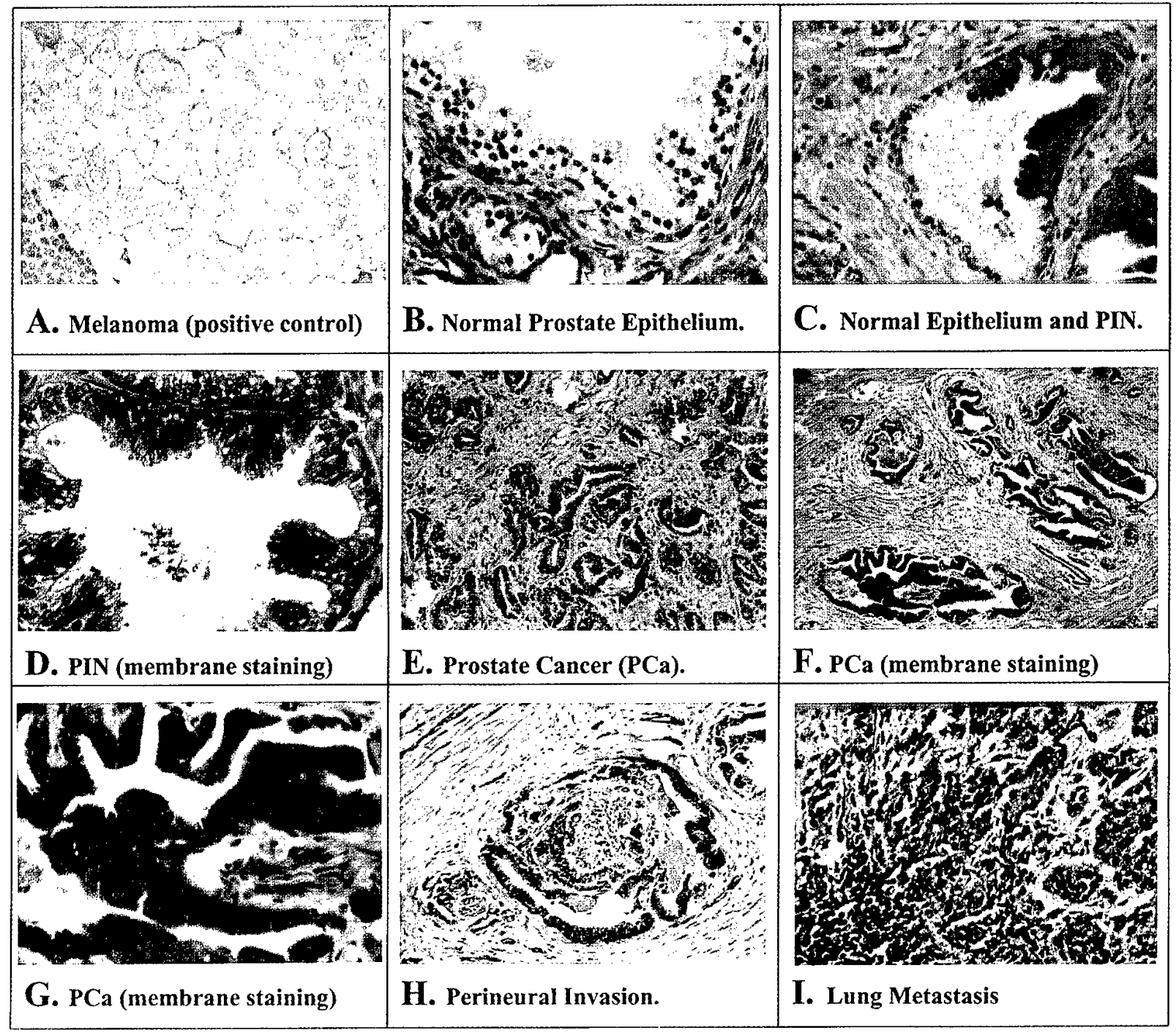

Fig. 8. Immunohistochemical analysis of the expression of huMUC18 protein in paraffin-embedded sections of human normal and neoplastic tissues of patients diagnosed as having malignant prostate cancer. Paraffin-embedded sections $(5 \mu \mathrm{m})$ from the tissue archive of Emory University Hospital were processed and immunohistochemically stained as described in Section 2. Antigen-retricval was carried out by steaming in citrate buffer ( $\mathrm{pH}$ 6.0) in a microwave oven for 20 min and cooled for $10 \mathrm{~min}$. The endogenous peroxidase was quenched with $3 \%$ hydrogen peroxide. An automated DAKO Autostainer (DAKO CO., Carpinteria, CA) was used. All tissuc sections were blocked with $5 \%$ non-fat milk for $2 \mathrm{~h}$, and reacted sequentially with the primary antibodies (1/640 dilution of the chicken anti-huMUC18 IgY) for $20 \mathrm{~min}$, a secondary antibody (1/80 dilution of the biotinylated anti-chicken IgY antibodies (G2891, Promega)) for $20 \mathrm{~min}$, a streptavidin-conjugated horseradish peroxidase complex (Dako LSAAB-2 system) for $20 \mathrm{~min}$, and diaminobenzidine as the chromogen for 5 min. The tissue sections were then counter-stained with hematoxylin for $1 \mathrm{~min}$. All these incubations were performed at room temperature; between incubations, sections were washed with Tris-buffered saline (TBS) buffer. The TBS buffer in negative controls replaced the primary antibody. All pictures were at $400 x$ magnification except $(\mathrm{E}),(\mathrm{H})$, and (I) at $200 \times$. and $(\mathrm{F})$ at $100 \times$ magnification. (A) Show the positive immunohistochemical signals (brown chromagen deposits) on the cellular surfaces and cytoplasm of a human malignant melanoma. (B) Shows negative signals in the luminal (or secretory) epithelial cells in the normal and benign hyperplastic portion of the prostate. (C) Shows a moderate intensity of immunoreactivity for the huMUC18 in the epithelial cells of highgrade prostatic intraepithelial neoplasia region (PIN) in a prostate gland. Note that negative signals are shown in normal secretory cells in the other half of the same duct-acinar. (D) Also shows a moderate intensity of immunoreactivity for the huMUC18 in the cytoplasm and cytoplasmic membranes of the epithelial cells of high-grade prostatic intraepithelial neoplasia region (PIN) in a prostate gland. (E) And (F) show strong positive signals in two prostate carcinomas (Glcason score of $3+4=7$ ). (G) Shows a higher magnification of $(\mathrm{F})$ with a strongly cytoplasmic membrane staining. (H) Shows a strong positive signal in a perineural invasion. (1) Shows strong positive signals in a lung metastases.

MUC18 expression might be at low levels, if at all, in the normal prostate gland and in the epithelial cells of the normal tissues, but its expression was increased in the preneoplastic (PIN) prostate gland.

\subsection{Expression of huMUC18 only in malignant tissue sections of prostatic cancers}

The result of analysis of tissue homogenates (Fig. 7) was 
Table 2

Comparison of the expression of huMUC18 in four prostate cancer cell lines with pertinent information published by other groups

\begin{tabular}{llllll}
\hline Properties/Cell lines & TSU-PR1 & DU145 & PC-3 & LNCAP & References \\
\hline MUC18 mRNA in total RNA & + & +++ & ++ & - & Our data \\
Human MUC18 protein & + & ++ & ++ & - & Our data \\
Relative level of E-cadherin expressed & 0 & 0.1 & 0.6 & 1.1 & Morton et al., 1993 \\
$\alpha$-catenin expressed & - & - & - & + & Morton et al., 1993 \\
Tumor growth in nude mice & ++++ & + & +++ & ++++ & Passaniti et al., 1992 \\
Relative motility in vitro & 21 & 12 & 5 & 1 & Our data \\
Relative invasiveness in vitro & 3 & 6 & 4 & 1 & Our data \\
Metastasis in nude mice & + & + & + & - & Lalani et al., 1997 \\
\hline
\end{tabular}

informative, but the specific histological structure and cell types that expressed the protein could not be identified. To further localize the expression of MUC18 in specific histological structures and cell types of the prostate gland, immunohistochemical analysis was carried out by using antihuMUC18 antibodies to stain paraffin-embedded tissue sections of prostatic adenocarcinomas. As an external positive antibody control, Fig. 8A shows that huMUC18 protein antigen was expressed in the cytoplasm and predominantly expressed on the cytoplasmic membrane of most melanoma cells. As internal positive controls, the smooth muscle cells and the endothelial cells in the major vasculatures in the stroma of the same tissue section, as well as histocytes (data not shown), also showed positive signals (Fig. 8B). This shows that our antibodies have a high specificity for recognition of cognate epitopes in these tissues. Fig. 8B also shows that huMUC18 was not, or weakly, expressed in the cytoplasmic membrane of the normal/hyperplastic epithelium. Fig. 8C,D show that huMUC18 was over-expressed in high-grade prostatic intraepithelial neoplasia (PIN) as compared to that in normal/hyperplastic epithelium in the same acinar/duct of the same tissue section (Fig. 8C). The number of PIN lesions varied from specimen to specimen and was usually in the range of 25 to $>300$ lesions per sample. Total number of PIN lesions examined was over 1000. Fig. 8E-G show over-expression of huMUC18 in primary carcinoma, as compared to the normal/hyperplastic epithelium on the same tissue section (Fig. 8C and data not shown) and also to that in Fig. 8B. MUC18 was also highly expressed in cells of a perineural invasion (Fig. $8 \mathrm{H}$ ), and a lung metastasis (Fig. 8I). Immunohistochemical staining of the normal/hyperplastic epithelium (BPH) was negative in $90 \%$ of the 32 specimens, or if positive in a few cases, staining was mainly restricted to basal cells (data not shown). In contrast, immunohistochemical staining in the high grade PIN and in malignant glands, including both primary and metastatic carcinoma, was positive in more than $80 \%$ of the specimens. From our preliminary survey, we found that immunohistochemical analysis of MUC18 expression in the normal and cancerous prostatic tissues showed a general trend of shifting from a predominant cytoplasmic membrane staining in the normal/hyperplastic epithelium $(100 \%)$ to mostly cytoplasmic staining in the high grade PIN (80\% as shown in Fig. $8 \mathrm{C}$ and $20 \%$ as shown in Fig. 8D) and primary carcinoma (90\% as shown in Fig. 8E and 10\% as shown in Fig. 8F,G).

\section{Discussion}

4.1. The level of huMUC18 $\mathrm{mRNA}$ and protein expression correlates with the in vitro motility and invasiveness and with the in vivo metastatic ability of the four prostate cell lines

We have presented evidence that both huMUC18 mRNA and protein are expressed in three prostate cancer cell lines, but not in one prostate cancer cell line. Table 2 shows that the expression of huMUC18 in these four cell lines is inversely related to the expression of E-cadherin and $\alpha$-catenin (Morton et al., 1993), and is positively related to their extent of in vitro motility and invasiveness (Fig. 6) and in vivo metastasis in nude mice (Table 2; Passaniti et al., 1992; Lalani et al., 1997). The unusual high motility of the TSU-PR1 cells (Fig. 6A) may be due to their smaller cell size and expression of a mutated huMUC18 variant (Table 1 and Fig. 2). The expression of huMUC18 is not correlated with their tumorigenicity in nude mice (Passaniti et al., 1992). Previously, Putz et al. (1999) failed to detect the MUC18 expression in three prostate cancer cell lines (DU145, PC-3, and LNCaP) by using two monoclonal anti-huMUC18 antibodies from Johnson's group for flow cytometry analysis. We could not conclusively explain the discrepancy, because these monoclonal antibodies were not available to us for comparison. First, their result was questionable, because both RT-PCR and Western blot analyses were not used for the analysis. Second, we also experienced the lacking ability of monoclonal antibodies to recognize the cognate epitopes of huMUC18 in prostate cancer cells, because we found that only one out of four monoclonal antibodies from Biocytex (France) showed positive signals in Western blot analysis of the extracts prepared from and also in immunohistochemistry of the three prostate cancer cell lines (DU145, TSU-PR1, and PC-3) (data not shown). In addition, several reasons may explain the above discrepancy: (a) the monoclonal antibodies recognize only one 
epitope that may not be extracellularly exposed in these cells or not accessible for interaction with the antibodies, (b) the monoclonal antibodies have a low affinity and avidity for recognizing the cognate epitopes, as they were made in a phylogenically close animal (mouse), since human MUC1 8 and mouse MUC18 have $76.2 \%$ identity in amino acid sequence (Yang et al., 2001). This may contribute to the high background of flow cytometry analysis and thus discount the result. (c) Our anti-human MUC18 polyclonal antibodies were made in phylogenically more distant chicken than mouse, and thus have a high affinity and avidity for recognizing the cognate epitopes. (d) Our polyclonal antibodies recognize multiple cognate epitopes of huMUC1 8 that contributed to strong positive signals. It should be noted that in addition to the proof of MUC18 protein expression in these cell lines, as analyzed by Western blot analysis, the MUC18 gene transcription in these cell lines was also confirmed by the results of Northern blot and RT-PCR analyses.

\subsection{Expression of huMUC18 increased with increasing malignancy of prostate cancers}

HuMUC18 protein was very weakly expressed in the extracts of cultured primary normal prostatic epithelial cells and a normal prostate gland, but was expressed at increasing levels in extracts prepared from the prostate tissue with high grade PIN. Further immunohistochemical analysis showed that MUC18 was expressed at higher levels in high grade PIN and primary and metastatic prostatic carcinomas over normal/hyperplastic (BPH) epithelium. Thus, the expression of MUC18 is greater in pre-malignant and cancerous epithelium than benign (normal or hyperplastic) prostate epithelium, suggesting its positive association with transformation and malignant progression. However, our result was discrepant from that of Shih et al., who previously reported negative results of MUC18 expression in both normal prostate gland and prostate carcinomas (Shih et al., 1998). Likewise, the reason for this discrepancy is not clear, since his monoclonal antibody, MN-4, was also not available for us to carry out comparative studies. The MN-4 monoclonal antibody probably has the similar problem of the four monoclonal antibodies from Biocytex that they failed to recognize the MUC18 epitopes in the formalinfixed cancerous prostate tissues. Although many variables between slides that may contribute to the discrepancy results of immunohistochemistry, we suggest a very likely possibility that some of MUC18 epitopes may not be exposed on the cellular surface or not accessible, or not retrievable from the formalin-fixed cancerous prostate tissues. It is highly possible that the MUC18 epitope in other tissues and other cancers (such as melanoma) is recognizable by $\mathrm{MN}$ 4 , but it is not accessible to the monoclonal antibody in cancerous prostate tissues, suggesting that the distinct intrinsic properties of different tissue may affect the presentation of huMUC18 on the cell surface. The above discre- pancy may suggest many unknown, interesting properties of huMUC 18 yet to be revealed.

\subsection{Increased expression of huMUC18 in prostate cancer tissues may be a marker for development and malignant progression of prostate cancer}

Aberrant expression of other cell adhesion molecules, such as E-cadherin, CD44, and C-CAM, has been associated with prostate cancer. Absent or reduced expression of these CAMs is associated with progression of prostatic carcinomas. However, the absence or reduction of an antigen during progression of malignant cancers may be a supportive, but not a practical diagnostic marker. In contrast, increased or over-expression of a neoplastic antigen may be very useful as a positive diagnostic marker during progression of cancers. The positive correlation of expression of huMUC18 in prostate cancer cells raises the possibility that it could be a useful marker for the emergence of pre-malignant, malignant and metastatic prostatic cancer. Human MUC18 may also be implicated as a mediator for metastasis of prostate cancers as seen in melanoma, although this requires further investigation.

\subsection{Lack of cytoplasmic membrane expression of huMUC18 may correlate with malignant progression of prostate cancer}

The lack of preferential expression of MUC18 in the cytoplasmic membranes of the cells in most PIN and prostatic adenocarcinomas is very interesting in that it may explain the lacking ability of above monoclonal antibodies to stain cancerous prostate tissues. This finding is consistent with the results obtained from the immunostaining of three established prostate cancer cell lines, which did not show predominantly cytoplasmic membrane staining (Fig. 5D,E). This could be due to that the same protein may behave differently in the context of different tissues and different cancers and thus the epitopes of the same protein exposed on the cellular surface of different tissues and different cancers may be different. This is consistent with our above prediction that MUC18 may play different multiple functions in different tissues. The precise reason for this unusual phenomenon requires further investigation. On possible explanation for the predominant cytoplasmic expression of MUC18 could be due to mutation or truncation of the MUC18 protein in cancer tissues. This is frequently observed in CAMs, growth factor receptors, and genes encoding for membrane proteins in prostate cancers and many other cancers (for an example in Grauer et al., 1998). Our preliminary result of analysis of the MUC18 cDNA sequence in the prostatic adenocarcinoma tissues implicated this possibility (Wu et al., 2000). But the significance of contribution of the altered MUC18 in development of prostatic cancers requires further investigation. From our preliminary survey, we did find a correlation of 
lacking predominant cytoplasmic membrane expression of MUC18 with malignant progression of prostate cancer.

\subsection{Conclusion}

1. We have isolated a major form of the $h u M U C 18 \mathrm{cDNA}$ gene.

2. We showed that three out of four prostate cancer cell lines expressed the huMUC18 mRNA and protein.

3. The expression of huMUC18 in these cell lines appeared to directly correlate with their higher in vitro motility and invasiveness and in vivo metastasis in nude mice.

4. We have shown combined immunological evidence from tissue cultures and tissues that MUC18 is usually absent in normal and benign hyperplastic tissues, but its expression increases during prostate cancer initiation (high grade PIN), progression to carcinoma, and in metastatic cell lines and metastatic carcinomas.

5. The lacking of predominant cytoplasmic membrane expression of MUC18 appeared to correlate with malignant progression of prostate cancer.

6. Taken all the results together, we suggested that overexpression of MUC18 is implicated to play some roles in developing and malignant progression of human prostate cancer. Our positive results of testing the effect of overexpression of MUC18 in LNCaP cells on increasing metastatic ability of this cell line support this hypothesis (Wu et al., unpublished results).

\section{Acknowledgements}

We thank Dr Abraham Philip for excellent technical help. We thank Dr Richard W. Compans for critical reading of this manuscript. This work was supported in part by a grant from the NCI's Developmental Program in Prostate Cancer (R21CA69764), in part by the Winship Cancer center seed grant, and in part by the Emory University Research Committee (G.-J. Wu). This work was also partly supported by a grant from NCI (R21CA69764) (J.A. Petros). This work was also supported by an USAMRMC prostate cancer center grant from the Department of Defense (PC992041) (G.-J. Wu, J.A. Petros, and M.B. Amin).

\section{References}

Ausubel, F.M., Brent, R., Kingston, R.E., Moore, D.D., Seidman, J.G., Smith, J.A., Struhl, K., (Eds.). Current Protocols in Molecular Biology. Green Publishing Associates and Wiley-Interscience Press, New York, 1987.

Bardin, N., Frances, V., Lesaule, G., Horschowski, N., George, F., Sampol, J., 1996. Identification of the S-Endo 1 endothelial-associated antigen. Biochem. Biophys. Res. Com. 218, 210-216.

Carter, H.B., Piantadosi, S., Isaacs, J.T., 1990. Clinical evidence for and implications of the multistep development of prostate cancer. J. Urol. $143,742-746$
Clark, E.A., Golub, T.R., Lander, E.S., Hynes, R.O., 2000. Genomic analysis of metastasis reveals an essential role for RhoC. Nature 406, 532535.

Chomczyuski, P., Sacchi, N., 1987. Single-step method of RNA isolation by acid guanidinium thiocyanate-phenol-chloroform extraction. Anal. Biochem. 162, 156-159.

Grauer, L.S., Lawler, K.D., Marignac, J.L., Kumar, A., Goel, A.S., Wolfert, R.L., 1998. Identification, purification, and subcellular localization of prostate-specific membrane antigen PAM $^{\prime}$ protein in the LNCaP prostatic carcinoma cell line. Cancer Res. 58, 4787-4789.

Iizumi, T., Yazaki, T., Kanoh, S., Kondo, I., Koiso, K., 1987. Establishment of a new prostatic carcinoma cell line (TSU-PRI). J. Urol. 137, 13041306.

Kawasaki, E.S., 1990. Amplification of RNA. In: Innis, M.A., Gelfand, D.H., Sninsky, J.J., White, T.J. (Eds.). PCR Protocols: A Guide to Methods and Applications, Academic Press, New York, pp. 21-27.

Lalani, E.N., Laniado, M.E., Abel, P.D., 1997. Molecular and cellular biology of prostate cancer. Cancer Metastasis Rev. 16, 29-66.

Landis, S.H., Murrays, T., Bolden, S., Wingo, P.A., 1999. Cancer statistics. CA Cancer J. Clin. 65, 5-27.

Lehmann, J.M., Holzmann, B., Breitbart, E.W., Schmiegelow, P., Riethmuller, G., Johnson, J.P., 1987. Discrimination between benign and malignant cells of the melanocytic lineage by two novel antigens, a glycoprotein with a molecular weight of 113,000 and a protein with a molecular weight of 76,000. Cancer Res, 47, 841-845.

Lehmann, J.M., Riethmuller, G., Johnson, J.P., 1989. MUC18, a marker of tumor progression in human melanoma. Proc. Natl. Acad. Sci. USA 86, 9891-9895.

Morton, R.A., Ewing, C.M., Nagafuchi, A., Tsukita, S., Isaacs, W.B., 1993. Reduction of E-cadherin levels and deletion of the $\alpha$-Catenin gene in human prostate cancer cells. Cancer Res. 53, 3585-3590.

Passaniti, A., Isaacs, J.T., Haney, J.A., Adler, S.W., Cujdik, T.J., Long, P.V., Kleinman, H.K., 1992. Stimulation of human prostatic carcinoma tumor growth in athymic mice and control of migration in culture by extracellular matrix. Int. J. Cancer 51, 318-324.

Pickl, W.F., Majdic, O., Fischer, G.F., Petzelbauer, P., Fae, I., Waclavicek, M., Stock, J., Scheinecker, C., Vidicki, T., Aschauer, H., Johnson, J.P., Knapp, W., 1997. MUC18/MCAM (CD146), an activation antigen of human T lymphocytes. J. Immunol. 158, 2107-2115.

Pignatelli, M., Vassey, C.J., 1994. Adhesion molecules: novel molecular tools in tumor pathology. Hum. Pathol. 25, 849-856.

Putz, E., Witter, K., Offner, S., Stosiek, P., Zippeliux, A., Johnson, J.P., Zahn, R., Riethmuller, G., Pantel, K., 1999. Phenotypic characteristics of cell lines derived from disseminated cancer cells in bone marrow of patients with solid epithelial tumors: establishment of working models for human micrometastases. Cancer Res. 59, 241-248.

Schlagbauer-Wadl, H., Jansen, B., Muller, M., Polterauer, P., Wolff, K., Eichler, H.G., Pehamberger, H., Konak, E., Johnson, J.P., 1999. Influence of MUC18/MCAM/CD146 expression on human melanoma growth and metastasis in SCID mice. Int. J. Cancer 81, 951-955.

Sciavolino, P.J., Abate-Shen, C., 1998. Molecular biology of prostate development and prostate cancer. Ann. Med. 30, 357-368.

Sers, C., Kirsch, K., Rothbacher, U., Riethmuller, G., Johnson, J.P., 1993. Genomic organization of the melanoma-associated glycoprotein MUC18: Implications for the evolution of the immunoglobulin domains. Proc. Natl. Acad. Sci. USA 90, 8514-8518.

Sers, C., Riethmuller, G., Johnson, J.P., 1994. MUC18, a melanomaprogression associated molecule, and its potential role in tumor vascularization and Hematogenous spread. Cancer Res. 54, 5689-5694.

Shih, I.-M., Hsu, M.-Y., Palazzo, J.P., Herlyn, M., 1997. The cell-cell adhesion receptor Mel-CAM acts as a tumor suppressor in breast carcinoma. Am. J. Path. 151, 745-751.

Shih, I.-M., Nesbit, M., Herlyn, M., Kurman, R.J., 1998. A new Mel-CAM (CD146)-specific monoclonal antibody, MN-4, on paraffin-embedded tissue. Mod. Pathol. 11, 1098-1106.

Tang, D.G., Honn, K.V., 1994-1995. Adhesion molecules and tumor metastasis: an update. Invasion Metastasis 14, 109-122. 
Toyoshima, M., Nakajima. M., 1999. Human heparanase: purification, characterization, cloning, and expression. J. Biol. Chem. 274, 2415324160 .

Umbas, R., Schalken, J.A.. Aalders, T.W., Carter, B.S., Karthaus, H.F.M., Schaafsma, H.E., Debruync, F.M.J., Isaacs. W.B., 1992. Expression of the cellular adhesion molecule E-cadherin is reduced or absent in highgrade prostate cancer. Cancer Res. 52, 5104-5109.

- Wu, G.-J., Wu, M.-W.H., Yang, H., Wang. S.-W.C., Sun, Q., Petros, J.A., Phlip, A., Amin, M.B., Varma, V.A., 1999. Human MUC18, a possible new marker for metastatic potential of prostate cancer, , Proceedings of the 90th annual meeting of American Association for Cancer Research, Philadelphia, PA, 236 (Abstract \#1568).

Wu, G.-J., Liu. Z., Peng, Q., Wang, S.-W., Wu, M.-W.H., Sun, Q., Keene,
T.E., Petros, J.A., 2000. Expression of a non-glycosylated of MUC18, a cell adhesion molecule, in a human prostate adenocarcinoma xenograft, , Proceedings of the 91st annual meeting of American Association of Cancer Research; 2000 April 1-5; Philadelphia, PA, 578, American Association of Cancer Research (Abstract \#3681).

Xie. S., Luca, M., Huang, S., Gutman, M., Reich, R., Johnson, J.P., Bar-Eli, M., 1997. Expression of MCAM/MCU18 by human melanoma cells leads to increased tumor growth and metastasis. Cancer Res. 57, 22952303.

Yang, H., Wang. S., Lit, Z., Wu, M.-W.H., McAlpine, B., Ansel, J., Armstrong, C., Wu, G.-J., 2001. Isolation and characterization of mouse MUC18 cDNA gene, and correlation of MUC18 expression in mouse melanoma cell lines with metastatic ability. Gene 265, 133-145. 


\section{Reactive oxygen generated by Nox1 triggers the angiogenic switch}

Jack L. Arbiser*t, John Petros*, Robert Klafter5, Baskaran Govindajaran*, Elizabeth R. McLaughlin*, Lawrence F. Brown", Cynthia Cohen", Marsha Moses $\star \star$, Susan Kilroy ${ }^{\star \star}$, Rebecca S. Arnold!, and J. David Lambeth ${ }^{+\|}$

Departments of *Dermatology, ${ }^{*}$ Urology, ${ }^{5}$ Hematology/Oncology, and Pathology Laboratory Medicine, Emory University School of Medicine, Atlanta, GA 30322; "Department of Pathology, Beth Israel Deaconess Hospital, Boston, MA 02215; and **Department of Surgical Research,

Children's Hospital and Harvard Medical School, Boston, MA 02115

Communicated by Douglas C. Wallace, Emory University School of Medicine, Atlanta, GA, November 27, 2001 (received for review May 7, 2001)

The reactive oxygen-generating enzyme Nox1 transforms NIH $3 T_{3}$ cells, rendering them highly tumorigenic and, as shown herein, also increases tumorigenicity of DU-145 prostate epithelial cells. Aithough Nox 1 modestly stimulates cell division in both fibroblasts and epithelial cells, an increased mitogenic rate alone did not account fully for the marked tumorigenicity. Herein, we show that Nox1 is a potent trigger of the angiogenic switch, increasing the vascularity of tumors and inducing molecular markers of angiogenesis. Vascular endothelial growth factor (VEGF) mRNA becomes markedly up-regulated by Nox1 both in cultured cells and in tumors, and VEGF receptors (VEGFR1 and VEGFR2) are highly induced in vascular cells in Nox1-expressing tumors. Matrix metalloproteinase activity, another marker of the angiogenic switch, also is induced by Nox1. Nox1 induction of VEGF is eliminated by coexpression of catalase, indicating that hydrogen peroxide signals part of the switch to the angiogenic phenotype.

D eactive oxygen species (ROS; superoxide, hydrogen peroxide, and their metabolites) are conventionally thought of as cytotoxic and mutagenic, and in high levels they induce an oxidative stress response $(1,2)$. However, recent evidence implicates lower levels of ROS as an intracellular mediator of growth, apoptosis, and senescence (2-6). For example, growth factors including platelet-derived growth factor and epidermal growth factor stimulate $\mathrm{H}_{2} \mathrm{O}_{2}$ generation through a pathway involving PI 3-kinase and Rac, and elimination of $\mathrm{H}_{2} \mathrm{O}_{2}$ with antioxidants prevents growth stimulation by these growth factors $(4,7-10)$.

Reactive oxygen may play a role in neoplastic growth, because a variety of cell lines derived from human cancers demonstrate significantly elevated $\mathrm{H}_{2} \mathrm{O}_{2}$ (6). NIH $3 \mathrm{~T} 3$ cells transformed with constitutively active Ras show elevated ROS, and antioxidants such as $\mathrm{N}$-acetyl cysteine reduce the abnormally rapid DNA synthesis in these cells $(11,12)$. Antioxidants enhance antitumor activity of conventional chemotherapeutic agents in rodents through unknown mechanisms (11). Tumor cells may be inherently more resistant to oxidative stress than normal cells, or oxidative stress may provide a selective advantage in tumor growth.

Nox1 (Mox1 in an earlier terminology), a recently identified (1) homolog of gp91phox, the catalytic subunit of the phagocyte superoxide-generating NADPH-oxidase, constitutively produces both superoxide and $\mathrm{H}_{2} \mathrm{O}_{2}$ when overexpressed in fibroblasts. Moreover, expression of Nox1 in these cells induces malignant transformation, rendering them highly tumorigenic in athymic mice (1). Decreased expression of endogenous Nox1 decreases proliferation of vascular smooth muscle, implicating Nox1 in normal cell growth. NIH 3T3 cells that stably express Nox1 exhibit modestly increased growth rates, but increased growth alone may be insufficient to account for the marked tumorigenicity of these cells. Coexpression of catalase along with Nox1 reverses the growth phenotype, rendering these cells poorly tumorigenic and indicating that one of the signaling species generated by Nox1 is $\mathrm{H}_{2} \mathrm{O}_{2}$ (13).
Microscopic dormant tumors are thought to occur relatively frequently, but few progress to form active tumors. Angiogenesis, the process by which tissues recruit and develop new blood vessels, is needed for tumors to grow beyond $1-2 \mathrm{~mm}$ in diameter (14). Progression to a growing tumor is characterized by induction in the tumor tissue of angiogenic factors, particularly vascular endothelial growth factor (VEGF) and matrix metalloproteinases (MMPs), and VEGF receptors (VEGFR) in the growing endothelial cells. The conversion to the angiogenic phenotype in previously dormant tumors is known as the "angiogenic switch". Because Nox1 causes aggressive growth of tumors in vivo that cannot be readily explained based on mitogenic rates alone, we tested the hypothesis that ROS produced by Nox1 triggers the angiogenic switch, permitting vascularization and rapid expansion of the tumor.

\section{Materials and Methods}

Cell Lines. NEF2 is a vector-control line developed from NIH 3T3 cells. YA28 and YA26 NIH 3T3 lines stably express Nox1 and are highly tumorigenic in nude mice (1). ZC-5 is a derivative of YA28 which coexpresses catalase along with Nox1; YA28/Z3 is a control Nox1-expresing line containing the empty catalase vector (13). DU-145 cells (American Type Culture Collection catalog no. HTB-81) were cultured in RPMI medium 1640 supplemented with 5\% (vol/vol) FBS. Transfection with Nox1 was performed as described for NIH 3T3 cells (1). Stable transfectants were cloned by dilution and culture in 96-well plates with selection for 5-7 passages. Fifteen clones were subcultured and tested for Nox1 mRNA by Northern blotting. Fourteen of these clones showed significant expression of Nox1. All experiments were repeated with at least three individual clones showing high Nox1 expression.

Cell Proliferation. Cells were grown in 12 wells of a 96-well plate by adding $1.75 \times 10^{3}$ cells in media with $10 \%$ (vol $/ \mathrm{vol}$ ) FBS. At $12 \mathrm{~h}, 1 \mu \mathrm{Ci}(1 \mathrm{Ci}=37 \mathrm{GBq})$ of $\left[{ }^{3} \mathrm{H}\right]$ thymidine was added to each well of the first plate, and at indicated times, plates were harvested on the Tomtec Cell Harvester (Tomtec, Orange, CT) to a filtermat. Filtermats were dried and counted on the Microlux Beta Counter. Data were averaged and plotted vs. time.

Reat-Time Reverse Transcription (RT)-PCR. Two-step quantitative RT-PCR was performed on CDNA generated by using the MultiScribe Reverse Transcriptase from the TaqMan Reverse Transcription System and the SYBR Green PCR Master Mix (Perkin-Elmer). Primers used were: actin (220 bp), forward,

Abbreviations: ROS, reactive oxygen species; VEGF, vascular endothellal growth factor VEGFR, VEGF receptor; MMP, matrix metalioproteinase; ISH, in situ hybridization.

tTo whom reprint requests should be addressed at: Department of Dermatology. Emory University School of Medicine, 1639 Pierce Drive, 5309 Woodruff Memorial Building, Atlanta, GA 30322. E-mall: jarbise

The publication costs of this article were defrayed in part by page charge payment. This article must therefore be hereby marked "advertisement" in accordance with 18 U.S.C. 51734 solely to indicate this fact. 

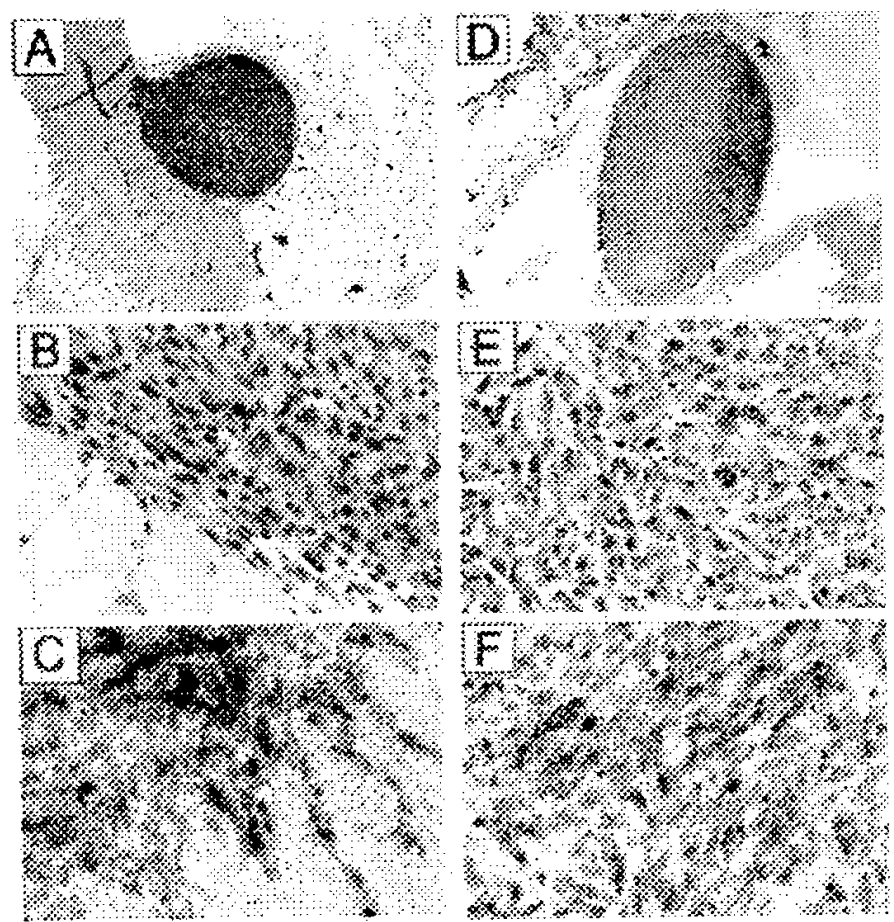

Fig. 1. Histologic and ISH studies of NEF2 and YA28 tumors. ( $A$ and $D$ ) Low-power (10X) views of NEF2 and YA28 tumors, respectively. ( $B$ and $E$ ) Higher-power views of NEF2 and YA28 tumors, respectively. Note the diffuse vascularity as indicated by the presence of red blood cells throughout YA28 in $E$, but the concentration of vessels at the periphery of NEF2 in $B$. ( $C$ and $A$ ) Histone H3 ISH (NEF2 and YA28, respectively).

AAA GAC CTG TAC GCC AAC ACA GTG CTG TCT GG and reverse, CGT CAT ACT CCT GCT TGC TGA TCC ACA TCT GC Nox1; Nox1 (506 bp), forward, ATA TTT TGG AAT TGC AGA TGA ACA and reverse, ATA TTG AGG AAG AGA CGG TAG TTT; VEGF (320bp), forward, TGCTGTCTTGGGTGCATTGG and reverse, GCATAATCTGCATGGTGATGTTGG. Reactions were performed in MicroAmp Optical 96-well Reaction Plate (Perkin-Elmer). Thirty-five PCR cycles were performed under standard conditions with an annealing temperature of $60^{\circ} \mathrm{C}$. Quantification was determined by the cycle number where exponential amplification began (threshold value), and values were averaged from the values obtained from the
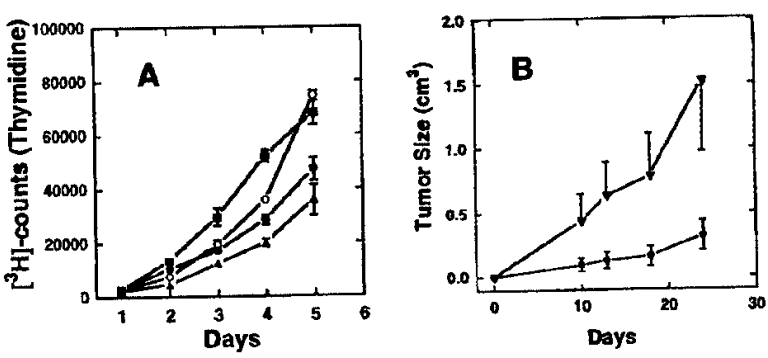

Fig. 2. Prostate cell proliferation and tumor growth are enhanced by Nox1. (A) Thymidine uptake in parental DU-145 human prostate cancer cells (A) was compared with that in DU-145 cells transfected with empty vector ( () and two separate Nox1-expressing cell lines (Nox3, $C$; and Nox6, $\square$ ). Points represent the average \pm SD of six wells. (B) In each group, six athymic mice were implanted s.c. with $10^{6}$ vector-control DU-145 cells $(\odot)$ or Nox1-expressing DU-145 cells $(\Delta)$. Tumor volumes were determined by bi-dimensional measurement, and average tumor volume was plotted vs. time. triplicate repeats. $\beta$-actin mRNA was used as a reference message to normalize the initial content of total cDNA. VEGF and Nox1 expression was calculated as the relative expression ratio of either VEGF or Nox1 threshold cycle to that of $\beta$-actin.
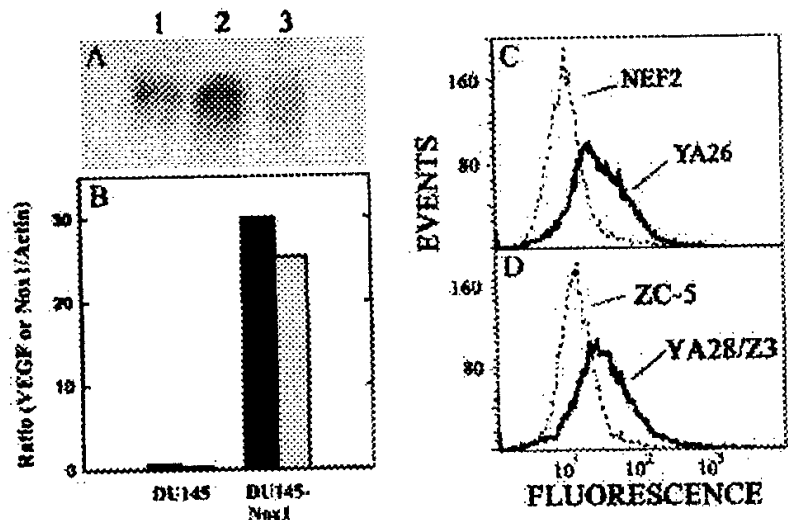

Fig. 3. Nox 1 induces VEGF expression dependent upon $\mathrm{H}_{2} \mathrm{O}_{2}$. (A) Northern blot analysis of Nox1 induction of VEGF mRNA and reversal by catalase. Lane 1. NEF2 (vector-control) cells; lane 2, Nox 1-expressing YA28 cells; lane 3, YA28 cells coexpressing catalase (ZC-5 cells; $10 \mu \mathrm{g}$ of total RNA per lane). (B) Nox1 mRNA (white bars) and VEGF mRNA levels (black bars) were quantified by mRNA (white bars) and VEGF mRNA levels (black bars) were quantified by real-time quantitative PCR in parental DU-145 cells (DU-145) and in Nox 1expressing DU-145 cells (DU-145-Nox1). Data shown are representative of three experiments and are expressed as the ratio to B-actin mRNA. (C) DCF fluorescence was monitored by flow cytometry in vector-control (NEF2) celis and in Nox1-expressing (YA26) cells. (D) As in C, monitoring Nox1-epressing YA26 cells coexpressing catalase (ZC-5) or the same cells transfected with vector alone (YA28/Z3). 

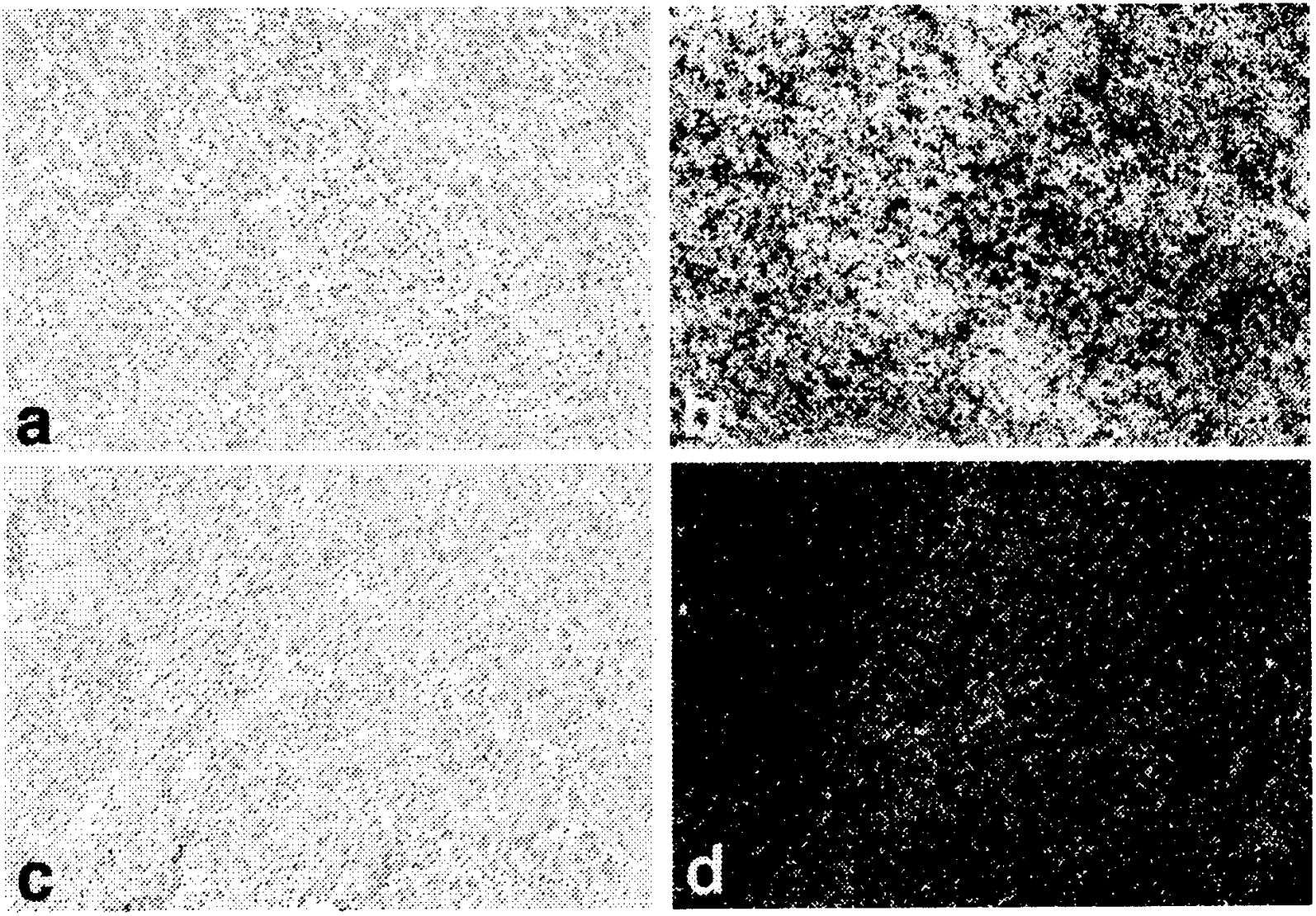

Fig. 4. Regulation of VEGF expression by Nox1 in vivo. Use of in situ high-level expression of VEGF mRNA is seen in YA28 tumors ( $a$ and $b$ ), whereas minima

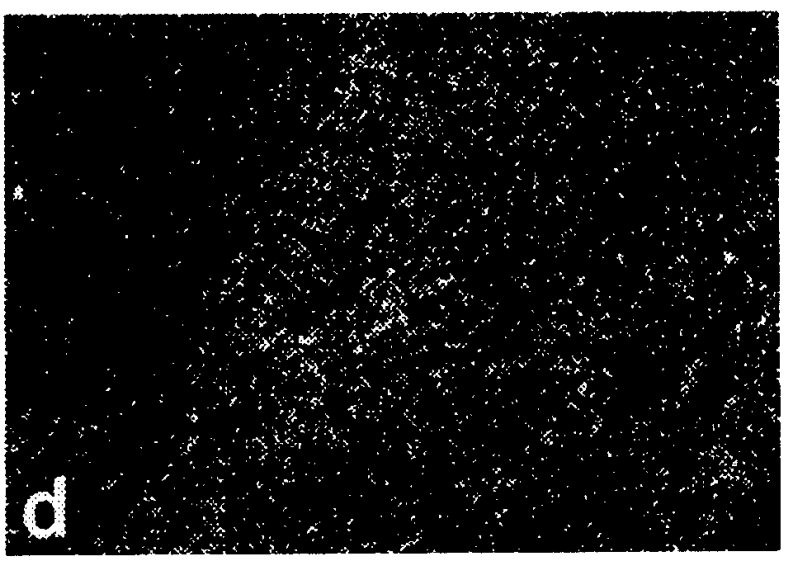
expression of VEGF is seen in NEF2 (control) tumors ( $c$ and $d$ ). (a and $c$ ) Brightfield photomicrographs. (b and of Darkfield photomicrographs.

All reactions were carried out in duplicate and threshold cycles were averaged.

Tumor Microvessel Density. Prostate cancer xenografts were fixed in formalin and processed according to standard methods. Sections were stained with smooth-muscle anti-actin antibody, and the number of vessels in several $200 \times$ fields were quantified according to a single blind protocol, as described $(15,16)$.

In Vive Tumorigenesis. One million cells were injected s.c. into 4 to 5-week-old male athymic mice (Charles River Breeding Laboratories) in the presence of a small quantity of trypan blue to mark the inoculation site. Tumors were excised after 1 month, fixed in formalin, and subjected to histologic analysis and in situ hybridization (ISH).

ISH. ISH was performed on 4-mm sections of formalin-fixed, paraffin-embedded tissue. Details of ISH have been reported $(17,18)$. Slides were processed through xylene and graded alcohols: $0.2 \mathrm{M} \mathrm{HCl} /$ Tris EDTA with $3 \mu \mathrm{g} / \mathrm{ml}$ proteinase $\mathrm{K} / 0.2 \%$ glycine $/ 4 \%$ (wt/vol) paraformaldehyde in PBS, $\mathrm{pH}$ 7.4/0.1 M triethanolamine containing $1 / 200(\mathrm{vol} / \mathrm{vol})$ acetic anhydride $/ 2 \times$ SSC. Slides were hybridized overnight at $50^{\circ} \mathrm{C}$ with ${ }^{35}$ S-labeled riboprobes in the following mixture: $0.3 \mathrm{M}$ $\mathrm{NaCl} / 0.01 \mathrm{M}$ Tris, pH $7.6 / 5 \mathrm{mM}$ EDTA $/ 0.02 \%$ (wt $/ \mathrm{vol}$ ) Ficoll $/ 0.02 \%$ (wt/vol) polyvinylpyrollidone $/ 0.02 \%$ (wt $/ \mathrm{vol}$ ) BSA fraction $\mathrm{V} / 50 \%$ (wt/vol) formamide $/ 10 \%$ (vol/vol) dextran sulfate $/ 0.1 \mathrm{mg} / \mathrm{ml}$ yeast tRNA/0.01 M DTT. Posthybrid- ization washes included $2 \times \mathrm{SSC} / 50 \%$ (wt/vol) formamide $/ 10$ $\mathrm{mM}$ DTT at $50^{\circ} \mathrm{C} / 4 \times \mathrm{SSC} / 10 \mathrm{mM}$ Tris $/ 1 \mathrm{mM}$ EDTA with 20 $\mu \mathrm{g} / \mathrm{ml}$ ribonuclease at $37^{\circ} \mathrm{C} / 2 \times \mathrm{SSC} / 50 \%$ (wt/vol) formamide $/ 10 \mathrm{mM}$ EDTA at $65^{\circ} \mathrm{C} / 2 \times \mathrm{SSC}$. Slides were dehydrated through graded alcohols containing $0.3 \mathrm{M}$ ammonium acetate, dried, coated with Kodak NTB 2 emulsion, and stored in the dark at $4^{\circ} \mathrm{C}$ for 2 weeks. The emulsion was developed with Kodak D19 developer, and the slides were counterstained with hematoxylin. ${ }^{35}$ S-labeled single-stranded antisense and sense RNA probes for mouse VPF/VEGF mRNA and the mouse VPF/VEGF receptors VEGFR-1 and VEGFR-2 mRNAs have been described $(17,18)$. Histone $\mathrm{H} 3$ ISH was performed on paraffin-fixed blocks (19).

Northern Blot Analysis. Poly(A) ${ }^{+}$mRNA was isolated from cells by using Oligotex Direct mRNA kit (Qiagen, Chatsworth, CA). Northern blot analysis was performed by using a murine VEGF probe ${ }^{32}$ P-labeled by random priming (20). Triplicate experiments were performed.

MMP Bioassay. Cells were grown to $\approx 75 \%$ confluence in DMEM with 5\% (vol/vol) FCS. After washing with PBS, media were replaced with Cellgro Serumless media (Mediatech, Herndon, VA) and incubated at $37^{\circ} \mathrm{C}$ in $10 \% \mathrm{CO}_{2}$ for $24 \mathrm{~h}$ (20). Substrate gel electrophoresis (zymography) was conducted according to Herron et al. (21) with modifications (20). The gels were stained with $0.5 \%$ Coomassie blue R-250 in acetic acid:isopropyl alcohol: $\mathrm{H}_{2} \mathrm{O}(1: 3: 6)$ and destained in 


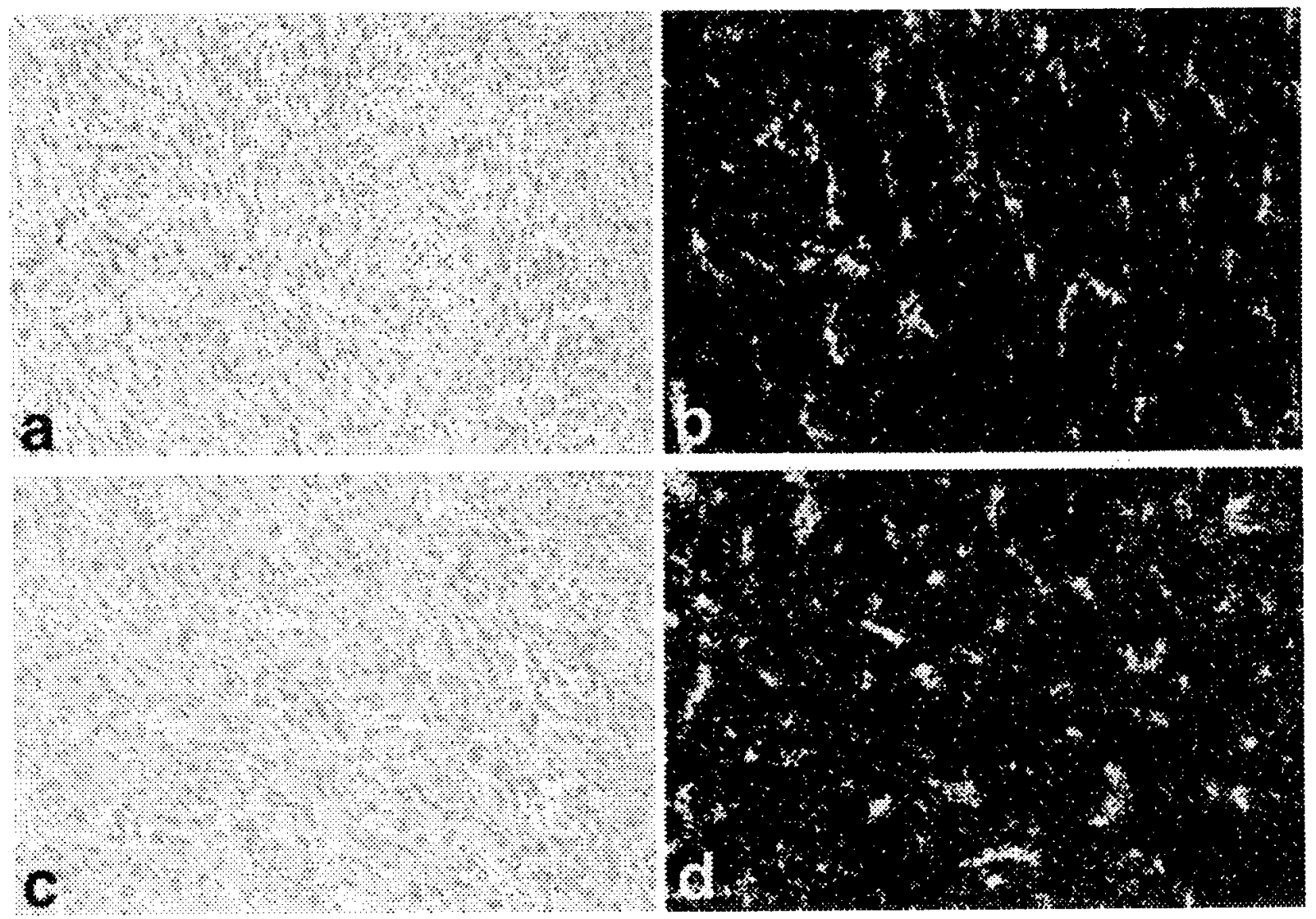

Fig. 5. Regulation of VEGFR1 and VEGFR2 expression by Nox 1 in vivo. 1SH reveals high-level expression of fit-1 (VEGFR1) ( $a$ and $b$ ) and kdr (VEGFR2) ( $c$ and $d$ ) mRNAs by endothelial cells in blood vessels in YA28 tumors. (a and $c$ ) Brightfield photomicrographs. (b and $d)$ Darkfield photomicrographs.

$\mathrm{H}_{2} \mathrm{O}$. Densitometry of destained areas was quantified with a Datascopy GS Plus scanner connected to a Macintosh II computer with MACIMAGE software (Xerox Imaging Systems, Palo Alto, CA).

Measurement of $\mathrm{H}_{2} \mathrm{O}_{2}$. Confluent cells in 100 -mm dishes $(\approx 5-6 \times$ $10^{6}$ cells) were washed with $6 \mathrm{ml}$ Hanks' balanced salt solution (HBSS) and released by using $0.25 \%$ trypsin (wt/vol) $/ 1 \mathrm{mM}$ EDTA followed by the addition of $5 \%$ (vol/vol) FBS in HBSS. After pelleting, cells were resuspended in 5\% (vol/vol) FBS in HBSS and counted. Dichlorofluorescein diacetate (DCFDA) was added to a final concentration of $2 \mu \mathrm{M}$ and incubated for $1 \mathrm{~h}$ in the dark at room temperature. Dichlorofluorescein (DCF) fluorescence was determined by using $0.5 \times 10^{6}$ cells per $3 \mathrm{ml} 5 \%$ (vol/vol) FBS in HBSS with a FACScalibur from Becton Dickinson (excitation wavelength, $488 \mathrm{~nm}$; emission wavelength, $515-545 \mathrm{~nm})$.

\section{Results}

Nox1 Converts Tumors from Dormant to Aggressive Growth. When Nox1-expressing NIH 3T3 cells were injected into athymic mice, large tumors were seen within $2-3$ weeks, as reported $(1,13)$ whereas no tumors were obvious with vector-control cells However, coinjection of a dye that permitted careful examination of the injection site revealed small dormant tumors, $\approx 1 \mathrm{~mm}$ in diameter. To our knowledge, microscopic tumor formation by nontransformed NIH 3T3 cells bas not been reported, but such tumors would be exceedingly difficult to detect without micro- scopic examination of the injection site. Tumors from both Nox1-expressing cells and control cells showed high expression of S-phase-specific $(22,23)$ histone $\mathbf{H 3}$, a marker of mitotically active cells (Fig. 1). Thus, although control NIH 3T3 derived tumors are highly proliferative, they remain microscopic in size, possibly because of apoptosis balancing growth. The finding of mitotic activity in a poorly angiogenic dormant tumor is similar to the observation of Holmgren et al. (24), who noted high proliferation in dotmant Lewis lung carcinomas of angiostatintreated mice. Therefore, Nox1 permits previously dormant tumors to grow aggressively and to achieve large size. Histologic examination (Fig. 1) revealed that the tumors from control cells are vascularized only at the periphery, and no blood vessels were seen at the interior of the tumor. However, tumors from Nox1-expressing cells are highly vascularized throughout the tumor, indicating that Nox1 triggers the angiogenic switch.

Similar results are seen with DU-145 cells, an epithelial line derived from a human prostate tumor. Expression of Nox1 resulted in a modest increase in cell growth in culture (Fig. $2 A$ ) similar to what was seen previously for NIH 3T3 cells (1) DU-145 cells typically produce slow-growing tumors when injected into athymic mice, as in Fig. $2 B$, $\bullet$. However, expression of Nox 1 resulted in a marked increase $(\approx 5$-fold $)$ in the rate of tumor growth (Fig. $2 B, \nabla$ ). Immunohistochemical examination of the control and Nox1 Du-145 tumors showed an increase in vascularity, with an average of 25.5 and 41.5 vessels per highpower field (four random fields evaluated) in the control and Noxl tumors, respectively. 


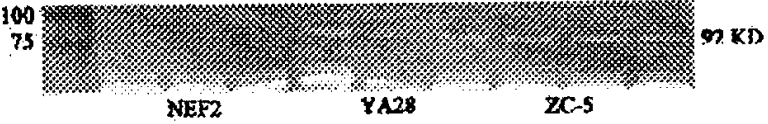

Fig. 6. Effect of Nox1 expression on MMP bioactivity. The first group of three lanes represents triplicate samples of conditioned media from NEF2 (vectorcontrol) cells; the second group of three lanes represents conditioned media from Nox1-expressing NIH 3T3 cells (YA28); and the third group of three lanes represents conditioned media from NIH $3 T 3$ cells overexpressing both Nox1 and catalase (ZEO5). The bands at $92 \mathrm{kDa}$ indicate gelatinolysis induced by MMP-9.

Nox1 Up-Regulates Expression of VEGF and Its Receptors. Dominant oncogenes such as V12Ras induce the angiogenic switch in part through induction of VEGF $(20,25)$. Nox1 expression led to an $\approx 4$-fold induction of VEGF mRNA by Northern blot analysis in NIH 3T3 cells (Fig. $3 A$ ) and a striking ( $\approx 30$-fold) increase in VEGF levels in DU-145 cells (Fig. $3 B$ ) by quantitative PCR. Expression of Nox1 led to an $\approx 10$-fold increase in $\mathrm{H}_{2} \mathrm{O}_{2}$ leveis in NIH 3T3 cells (Ref. 13 and Fig. 3C) and a similar increase in DU-145 cells (data not shown). Stable coexpression of catalase in Nox1-expressing NIH 3T3 cells decreased the steady-state intracellular concentration of $\mathrm{H}_{2} \mathrm{O}_{2}$ by several-fold (Fig. $3 D$ ). Catalase coexpression, which markedly diminishes the tumorigenicity of Nox1-expressing cells (13), resulted in reversion of Nox1-associated VEGF expression to near-control levels (Fig. $3 A$ ). Thus, $\mathrm{H}_{2} \mathrm{O}_{2}$ generated by Nox1 mediates the induction of VEGF.

To determine VEGF and VEGFR expression in tumors, ISH was carried out for VEGF (Fig. 4), VEGFR1, and VEGFR2 (Fig. 5). High-level expression of VEGF, VEGFR1, and VEGFR2 was seen in YA28 tumors, with VEGF expression localized to the tumor tissue itself, and VEGFR1 and VEGFR2 (Fig. $5 b$ and $d$, respectively) localized in a pattern characteristic of newly growing blood vessels. Little hybridization with any probe was observed in control tumors.

Nox1 Regulates MMP Bioactivity. Dominant oncogenes also induce MMP bioactivity as part of the angiogenic switch $(19,20,25,26)$. MMPs are required for invasive and malignant growth, and high levels of MMP expression contribute to neoplastic progression $(20,25,27,28)$. Zymographic analysis was carried out by using conditioned media from vector-control and Nox1-transformed cells. Nox1 expression induces gelatinolytic activity, which is predominantly MMP-9 indicated by migration at $92 \mathrm{kDa}$ (Fig. 6). Catalase coexpression failed to revert Nox1-induced bioactivity of MMP, indicating that although MMP is regulated by Nox1, the regulation differs from that of VEGF.

\section{Discussion}

Recent evidence implicates ROS in mitogenic signaling by growth factors and oncogenes $(7,12,29,30)$. In addition, the presence of oxygen-derived free radicals contributes to tumor resistance to chemotherapy, and combination therapy using both

1. Suh, Y.-A., Amold, R. S., Lassegue, B., Shi, J., Xu, X., Sorescu, D., Chung A. B., Griendling, K K. \& Lambeth, J. D. (1999) Nature (London) 401, 79-82.

2. Pentland, A. P., Morrison, A. R., Jacobs, S. C., Hruza, L. L., Hebert, J. S. \& Packer, L. (1992) J. Biol. Chem. 267, 15578-15584.

3. Nakahara, H., Kanno, T., Inai, Y., Utsumi, K, Hiramatsu, M., Mori, A \& Packer, L. (1998) Free Radical Biol. Med. 24, 85-92.

4. Esposito, L. A., Melov, S., Panov, A, Cottrell, B. A. \& Wallace, D. C. (1999) Proc. Natl. Acad. Sci. USA $96,4820-4825$.

5. Dang, C. V. \& Semenza, G. L. (1999) Trends Biochem. Sci. 24, 68-72.

6. Szatrowski, T. P. \& Nathan, C. F. (1991) Cancer Res. 51, 794-798

7. Lee, A. C., Fenster, B. E., Ito, H., Takeda, K., Bae, N. S., Hirai, T., Yu, Z. X., Ferrans, V. J., Howard, B. H. \& Finkel, T. (1999) J. Biol. Chem. 274, 7936-7940. antioxidants and chemotherapeutic agents is being investigated (11). The mechanism of ROS generation in malignant cells is not understood fully but may involve induction of ROS-generating enzymes (e.g., Nox1), byproducts of oxidative metabolism (as is seen in the generation of melanin by melanocytes), or de novo synthesis of ROS through defective respiration (often seen in cancer cells; refs. 6 and 31).

The Nox1 gene transforms NIH 3T3 cells, rendering them capable of forming well vascularized tumors, whereas the parent cells form microscopic dormant tumors that are poorly vascularized. Similarly, Nox1 expression converts DU-145 epithelial cells from weak to strong tumorigenic potential, with a corresponding increase in tumor vascularity, pointing to the generality of the angiogenic effect of Nox1. The molecular mechanism by which Nox1 causes this dramatic increase in tumorigenicity and angiogenesis involves the induction of VEGF and MMP, proangiogenic mediators that are important for tumor growth and invasion $(21,23,25,26,29,30)$. Nox1 increased both the synthesis of VEGF mRNA and the bioactivity of MMP-9 to levels similar to those seen in Ras-transformed angiosarcoma cells (20). Even in the absence of vascularization, the small dormant tumors arising from control NIH 3T3 cells are characteristic of the expression of histone $\mathrm{H3}$, a marker of active cell proliferation (18). Growth in these dormant tumors is likely to be counterbalanced by loss of cells through apoptotic cell death. Vascularization may not only provide the tumor with nutrients and oxygen, but it probably also delivers regulatory factors that prevent apoptotic cell death, thus allowing tumor expansion, as noted $(15,32,33)$.

The present studies also demonstrate that Nox1 signals angiogenic and tumorigenic effects in part through $\mathrm{H}_{2} \mathrm{O}_{2}$. Introduction of catalase reversed Nox1 induction of VEGF but did not affect the induction of MMP-9, suggesting either that MMP activation is linked to a different Nox1-generated signal (perhaps superoxide), or that it has a lower threshold for induction by $\mathrm{H}_{2} \mathrm{O}_{2}$ (34), which may remain somewhat elevated in Nox1 cells after coexpression of catalase (13). In preliminary studies, we found that Nox1 activates several pathways that have previously been implicated in growth and angiogenesis, including NF $\kappa$-Bdependent transcription and the ERK1/2 pathway (D. R. Ritsick, unpublished work). Our findings suggest that in proliferating cells expressing Nox1, pharmacologic inhibition of Nox1 activity and/or pharmacological lowering of cellular $\mathrm{H}_{2} \mathrm{O}_{2}$ levels may lead to decreased in vivo proliferation and increased chemosensitivity to therapeutic agents.

This work was supported by the American Skin Association and National Institute of Arthritis and Musculoskeletal and Skin Diseases Grant AR47901 (to J.L.A.), Emory Skin Discase Research Core Center Grant P30, National Institutes of Health Grants AR42687 and AR02030 (to J.L.A.), National Institutes of Health Grant CA84138 (to J.D.L.), Department of Defense Grant BC995541 (to J.P.), and Research Scientist Development Award (to J.P.) and Department of Defense Grant DAMD 17-00-1-0080 (to J.P., R.S.A., and J.D.L.). M.M. is supported by Grant 83821 from the American Cancer Society.

8. Zhu, J., Woods, D., McMahon, M. \& Bishop, J. M. (1998) Gener Dev. 12 2997-3007.

9. Yeh, L. H., Park, Y. J., Hansalia, R. J., Ahmed, I. S., Deshpande, S. S., Goldschmidt-Clermont, P. J., Irani, K. \& Alevriadou, B. R. (1999) Am. J. Physiol. 276, C838-C847.

10. Freeman, J. L, Abo, A. \& Lambeth, J. D. (1996) J. Biol. Chem. 271, 19794-19801.

11. Chinery, R., Brockman, J. A., Peeler, M. O., Shyr, Y., Beauchamp, R. D. \& Coffey, R. J. (1997) Nat. Med. 3, 1233-1241.

12. Irani, K., Xia, Y., Zweier, J. L., Sollott, S. J., Der, C. J., Fearon, E. R. Sundaresan, M., Finkel, T. \& Goldschmidt-Clermont, P. J. (1997) Science 275 $1649-1652$.

13. Arnold, R. S., Shi, J., Murad, E., Whalen, A., Sun, C. Q., Parnathysarathy, S., 